\title{
MÜTESELSİL BORÇLULUKTA RÜCU ZAMANAŞIMINA İLIŞKIIN BAZI SORUNLAR
}

Serkan AYAN*

\section{$\ddot{O} Z$}

Müteselsil borçluluk; alacaklının, kanun veya sözleşme gereğince alacă̆ının tamamını veya bir kısmını, birden çok borçlunun birinden veya tamamından isteme hakkına sahip olduğu bir borçtürüdür. Müteselsil borçlulukta borçluların sorumluluğu, borcun tamamı ifa edilene kadar devam eder. Ancak borçlulardan birinin borcun tamamını ifa etmesiyle tüm müteselsil borçluların alacaklıya karşı olan sorumluluğu sona erer. Bu aşamadan sonra ise borçlular arasında iç hesaplaşma gerçekleşir.

Müteselsil borçlu, alacaklıya karşl, borçlular arasındaki hukuki ilişkiye göre borcun bir kısmını karşılaması gerektiği yönünde bir savunma yapamaz. Bu sebeple, iç ilişkide sorumlu olduğundan daha yüksek tutarda bir borcu ifa etmek zorunda kalabilir.

Bunun sonucu olarak da, iç ilişkideki payından fazla bir tutarda ifada bulunan müteselsil borçlu, diğer koşullar da varsa, payını aşan kısmı diğer müteselsil borçlulardan talep edebilir.

Bu talebin bağlı olduğu zamanaşımı süresi, müteselsil borçlular arasında bir sözleşme ilişkisi varsa, bu sözleşme hükümlerine göre belirlenen zamanaşımı süresine bağlıdır. Müteselsil borçlular arasında bir sözleşme ilişkisi yoksa, bu kez de rücu alacă̆ının hukuki dayană̆ına göre zamanaşımı süresi belirlenir.

Anahtar Kelimeler: Müteselsil Borçluluk, Müteselsil Sorumluluk, Rücu, Halefiyet, Zamanaşımı.

\section{SOME ISSUES ARISEN FROM PRESCRIPTION OF REVOCATION IN JOINT INDEBTNESS}

\section{ABSTRACT}

Joint indebtness; is a type of debt in which creditor has the right to request all or the debt's part as required by law or contract, from one or all of the multiple debtors. In joint indebtness, the debtors' liability continues until entire debt is fulfilled.

* Doç. Dr., Dokuz Eylül Üniversitesi Hukuk Fakültesi Medeni Hukuk ABD. Öğretim Üyesi, e-posta: serkanayan@yahoo.com,

ORCID ID: 0000-0002-9788-8792.

DOI : 10.34246/ahbvuhfd. 812926

Yayın Kuruluna Ulaştığı Tarih : 26/07/2020

Yayınlanmasının Uygun Görüldüğ̈̈ Tarih: 09/10/2020

Ankara Hacı Bayram Veli Üniversitesi Hukuk Fakültesi Dergisi C. XXIV, Y. 2020, Sa. 43 
However, when one of debtors performs entire debt, all the various debtors' liability towards creditor ends. Hereafter, internal accouting occurs between debtors.

The joint debtor cannot make defense against creditor that he/she should meet the debt's part according to legal relationship between debtors. Therefore, the debtor may have to perform higher amount of debt than he/she is responsible for in internal relationship.

As result, the joint debtor, who performs more than share in internal relationship, may request portion exceeding his/her share from other joint debtors, if other legal conditions exist.

If there's a contractual relation between debtors, the prescription which demand depends on the revocation will depend on the prescription period determined according to terms of this contract. If there's no contractual relation between joint debtors, determination of the prescription period depends on legal basis of revocation.

Keywords: Joint indebtness, Joint Liability, Revocation, Subrogation, Prescription.

\section{GíRIŞ}

Bilindiği gibi müteselsil borçluluk; alacaklının, Kanun veya sözleşme gereğince alacağının tamamını veya bir kısmını, birden çok borçlunun birinden veya tamamından isteme hakkına sahip olduğu; borçluların sorumluluğunun da borcun tamamı ifa edilene kadar devam ettiği, ancak borçlulardan birinin borcun tamamını ifa etmesiyle alacaklıya karşı olan sorumluluğun sona erdiği, bu aşamadan sonra borçlular arasında iç hesaplaşmanın gerçekleştiği birlikte borçluluk ${ }^{1}$ türünü ifade eder ${ }^{2}$.

Müteselsil borçluluk kanunda belirtilen istisnai durumlarda ortaya çıkabileceği gibi, tarafların idaresinden de doğabilir. Hukukumuzda, müteselsil borçluluğun istisna, paylı borçluluğun ise kural olduğu kabul edilmiştir (TBK 162).

1 Birlikte borçluluk üst kavramı ve bu konudaki alt ayrımlar için bkz. BUCHER, s. 486 vd; GAUCH / SCHLUEP / EMMENEGGER, no. 3685 vd; AKINTÜRK, s. 4 vd; KAPANCI, (2014), s. 3 vd: KAPANCI, (2019), m. 162-168, no. 4 vd.; ŞAHIN CANER, s. 2 vd; TERCIER / PICHONNAZ / DEVELIOĞLU, no. 1599 vd.

2 VON TUHR, s. 785; BUCHER, s. 491; KOLLER, s. 1199; GAUTSCHI, s. 4; KARAYALÇIN, s. 109; TEKINAY / AKMAN / BURCUOĞLU / ALTOP, s. 285; AKINTÜRK, s. 35; KIRCA, s. 24; ŞAHIN CANER, s. 10; ALTAY, s. 393; AYAR / ENGIN, s. 1293; TURANBOY, no. 3; AŞIK, s. 5; ARAT, s. 326. 
Kanundan doğan müteselsil borçluluğun tipik (ilk akla gelen) örnekleri, aynı zarardan (geniş anlamda) haksız fiil hükümlerine göre sorumlu olanların borçluluğu (TBK 61) ile; kanunda veya sözleşmede aksi öngörülmedikçe, borçlulardan en az biri için ticari nitelik taşıyan bir iş nedeniyle birden çok kişinin birlikte borçlanmasıdır (TTK 7) ${ }^{3}$. Bu sebeple müteselsil borçluluk denince, diğer müteselsil borçluluk hallerinin yanında, hem sözleșme hükümleri, hem de haksız fiil hükümleri gereğince birden çok kişinin borcun tamamı için borçlu olması kastedilmektedir.

Müteselsil borçlulukta borçluların her biri alacaklıya karşı borcun tamamından sorumludur. Alacaklı, borcun tamamını bir borçludan talep ve tahsile yetkilidir. Fakat dış ilişkideki bu durum gereğince borcun tamamını ifa etmek zorunda kalan müteselsil borçlu, iç ilişkideki borca katılma payını aşan miktardaki ödemesi için diğer müteselsil borçlulara rücu etme hakkına sahiptir (TBK 62 / II ve TBK 167 / II). Borçlular arasındaki iç hukuki ilişkiden doğan özel rücu hakkı olarak anılan bu imkânın yanında, ifada bulunanın alacaklıya halef olması da sağlanarak, rücu hakkının kolaylaştırılması amaçlanmıştır. Halefiyet yoluyla, asıl borç ilişkisi için geçerli olan teminatların, rücu hakkının teminatı olarak kullanılması sağlanmaya çalışılmıştır.

$\mathrm{Bu}$ çalışmada, müteselsil borçlulukta, alacaklıya karşı kendi payından fazlasını ifa eden / etmek zorunda kalan borçlunun, diğer müteselsil borçlulara rücu hakkının bağlı olduğu zamanaşımı sorunu incelenecektir.

\section{ALACAKLI İLE MÜTESELSIL BORÇLULAR ARASINDAKİ (DIŞ) İLIŞSKI}

Müteselsil borçluluğun temel özelliği, alacaklı karşısında her bir borçlunun borcun tamamından sorumlu olmasıdır ${ }^{4}$. Alacaklı, dilerse bir borçluya başvurup borcun bir kısmının veya tamamının ifasını isteyebilir. Kendisine başvurulan borçlu, borcun bir kısmından sorumlu olduğu yönünde bir savunma (bölme def'i) yapamaz'. Fakat bu alacaklar arasında yarışma

3 Kanunda doğan diğer müteselsil borçluluk halleri için bkz. GAUTSCHI, s. 28 vd; KOLLER, s. 1206; AKINTÜRK, s. 123 vd; KILIÇOĞLU, (2014), s. 747; ŞAHIN CANER, s. 79 vd; DALCI ÖZDOĞAN, s. 60 vd; KAPANCI, (2014), s. 51. HMK 326 / III hükmünün, mahkeme kararından doğan bir müteselsil borçluluk ilişkisi yaratabileceği yönünde: KILIÇOĞLU, (2014), s. 750; KAPANCI, (2014), s. 52.

4 Müteselsil borçlulukta diş ilişsi, inceleme konumuz değildir. Fakat iç ilişkideki rücu mekanizmasının açıklanabilmesi için, dış ilişkideki hukuki durumun ana hatlarıyla, ilgili olduğu ölçüde kısaca belirtilmesinde yarar vardır.

5 EREN, s. 1344; TEKINAY / AKMAN / BURCUOĞLU / ALTOP, s. 285; KILIÇOĞLU, 
bulunmaktadır. Borçlulardan biri borcun tamamını ifa edince, borç sona erer ${ }^{6}$.

818 sayılı önceki Borçlar Kanunu döneminde sorumluluk hukuku için kabul edilmiş bulunan eksik teselsül - tam teselsül ayrımında, sorumluların aynı hukuki sebepten mi, yoksa farklı hukuki sebepten mi sorumlu tutulduklarına göre farklı hukuki rejimin uygulanmasının gerektiği ${ }^{7}$, bu farklılı̆̆ın, özellikle konumuzla ilgili olarak şu üç noktada ortaya çıktığı kabul edilmekteydi.

- Tam teselsülün aksine eksik teselsülde, her bir sorumlunun, zarardan tek başına sorumlu olsaydı ne miktarda sorumlu tutulacaksa, diş

(2014), s. 750; OĞUZMAN / ÖZ, (2017), no. 850; GAUTSCHI, s. 6; KAPANCI, (2014), s. 53; KAPANCI, (2019), m. 61-62, no. 1; BAYSAL, s. 615; ACAR, (2010), no. 20 vd; DALCI ÖZDOĞAN, s. 42; ŞAHIN CANER, s. 44; TERCIER / PICHONNAZ / DEVELİOĞLU, no. 1625 vd; NOMER, (2015), s. 198; TURANBOY, no. 6; ARAT, s. 329.

Bu yönüyle müteselsil borçluluğun, alacaklı için bir paşa konumu yarattığı ifade edilmiştir.

Doktrinde farklılaştırılmış teselsül olarak anılan ve TBK Tasarısında bulunmasına rağmen, Kanuna alınmayan bu hukuki kurumda, müteselsil borçlulardan her biri, zarara yol açan fiile tek başına sebep olsaydı ne miktarda sorumlu olacak idiyse, dış ilişkide de o miktarda sorumlu olmaktadır. Buna göre, hiçbir sorumlu, sırf yanında başka sorumlu(lar) da var diye, zarardan tek başına sorumlu olması halinde ödeyeceği tazminattan daha yüksek bir tazminatla sorumlu tutulmamalıdır. Bkz. EREN, s. 924 vd. NOMER, (2012), s. 57; KAPANCI, (2014), s. 36; KAPANCI, (2019), m. 61-62, no.20; KIRCA, s. 38; YAĞCIOĞLU, s. 117 vd; ŞAHIN CANER, s. 21; GÜRPINAR, s. 278.

Farklılaştırılmış teselsülün hukukumuzdaki somut yasal örneği olan TTK 557 hükmü hakkında bkz. KAPANCI, (2014), s. 40 vd; YAĞCIOĞLU, s. 137 vd; AKDAĞ GÜNEY, s. 1207 vd; GÖKTÜRK / CAN, s. 247 vd.

Doktrinde Acar, farklılaştırılmış teselsülün Türk Borçlar Kanuna alınmamış olması nedeniyle sorunlar yaşanacağını beyan etmiş ve buna ilişkin olarak şu örneği vermiştir: Yazarın müteselsil borçlu olarak kabul ettiği zorunlu mali sorumluluk sigortacısının limiti mesela 20.000 TL olmasına rağmen, işletenin KTK 85 gereğince sorumlu olduğu maddi zarar toplam1 30.000 TL ise, sigorta şirketi 30.000 TL ödemek zorunda kalacaktır. Bkz. ACAR, (2011), s. 345 .

6 Müteselsil borçta borcun tamamı borçluların biri tarafindan ifa edilince aslında borç tamamen sona ermeyebilir. Borcu ifa eden müteselsil borçlu, rücu hakkı ölçüsünde alacaklının yerine geçer, alacakliya halef olur. Bu sebeple, metinde geçen borç sona erer ibaresi, anlatımı sağlayabilmek için kullanılmıştır.

$\mathrm{Bu}$ yönüyle halefiyetin, ifa ve alacak temlikinden müteşekkil bir hukuki yapısının bulunduğu, doktrindeki bir görüşte haklı olarak kabul edilmiştir: KILIÇOĞLU, (1979), s. 9; KAPANCI, (2014), s. 386. Bkz. FRANKO, Halefiyet I, s. 202 vd; OĞUZMAN / ÖZ, (2018), no. $284 \mathrm{vd}$.

Çalışmamızın kapsamı dışında tuttuğumuz bu konuda bkz. KARAYALÇIN, s. 112; KAPANCI, (2019), m. 61-62, no. 8 vd; KILIÇOĞLU, (2014), s. 457; DALCI ÖZDOĞAN, s. 76 vd; OĞUZMAN / ÖZ, (2017), no. 837 vd; KIRCA, s. 23 ve özellikle s. 36 vd; ŞAHİN CANER, s. 15 vd; VON TUHR, s. 408 vd; NOMER, (2015), s. 200; NOMER, (2012), s. 56; GÜRPINAR, s. 276; KURT, s. 138; ÇAVUŞOĞLU IŞINTAN, s. 504; AŞIK, s. 8; GAUTSCHI, s. 63 vd. 
ilişkide bu miktardan müteselsilen sorumlu sayılması.

- $\quad$ Tam teselsülün aksine eksik teselsülde, zamanaşımının bir müteselsil borçlu için kesilmesi halinde, bunun diğerleri için de zamanaşımının kesilmesi sonucunu doğurmayacağının kabul edilmesi ${ }^{8}$.

- Eksik teselsülde, rücu aşamasında halefiyetin söz konusu olmaması ${ }^{9}$.

6098 sayılı Türk Borçlar Kanununda ise, eksik - tam teselsül ayrımı terk edilmiş olup, sorumluluk ister aynı hukuki sebepten, isterse de farklı hukuki sebepten kaynaklansın, sorumluların hukuki durumu yeknesaklaştırılmıştır. $\mathrm{Bu}$ sebeple, yukarıda açıklanan (konumuzla ilgili) üç özel farklılık artık ortadan kalkmıştır ${ }^{10}$.

Doktrindeki hâkim görüşte, müteselsil borçlulukta, alacaklı ile her bir borçlu arasında ayrı borç ilişkilerinin doğduğu kabul edilmektedir ${ }^{11}$. Borcun çokluğu görüşü olarak isimlendirilen bu görüş gereğince alacaklının hakk1, birden çok borçluya yönelen tek bir alacak olmayıp, borçluların her birine karş1 ayrı ayrı yönelen ve birbirileriyle yarışma halinde bulunan birden çok alacaktan oluşur. Bu sebeple her bir borçlunun borcunun muacceliyeti, temerrüdü ve zamanaşımının işlemeye başlaması / durması birbirinden farklıdır ${ }^{12}$.

Borcun çokluğu görüşünün sonucu olarak müteselsil borçlulukta, her bir borçlunun borcunun zamanaşımı süresi, diğerinden bağımsız olarak işler. $\mathrm{Bu}$ durum zamanaşımı yönünden üç noktada farkl1lık yaratabilirri3:

8 BAYSAL, s. 610; ACAR, (2011), s. 341; OĞUZMAN / ÖZ, (2018), no.1956; KILIÇOĞLU, (2014), s. 464; KILIÇOĞLU, (2007), s. 165; YAĞCIOĞLU, s. 235.

İsviçre hukukunda uygulama ve doktrindeki hâkim görüş de bu yöndeydi: ROTHENBERGER, s. 97; VERDE, (2019), s. 129. BGE 127 III 257, E.6a.

9 Bu konudaki görüşler ve yargı kararları için bkz. KURT, s. 141.

10 KURT, s. 150. Fakat ifade etmek gerekir ki, özellikle eksik teselsül olarak anılan durumda, zamanaşımının kesilmesinin diğer borçluları da etkilemesi görüşünün, yeni Kanun döneminde de tartışmaya açık olduğu söylenebilir. Bu konuyu ayrı bir çalışmada ele almayı planladığımızdan, soruna işaret etmekle yetinmeyi uygun görmekteyiz.

11 EREN, s. 1343; TEKINAY / AKMAN / BURCUOĞLU / ALTOP, s. 288; OĞUZMAN / ÖZ, (2017), no.1341; KAPANCI, (2014), s. 28; KAPANCI, (2019), m. 162, no. 5 vd; KIRCA, s. 25; YAĞCIOĞLU, s. 67; DALCI ÖZDOĞAN, s. 32; ŞAHİN CANER, s. 40.

12 VON TUHR, s. 787; GAUTSCHI, s. 126; KAPANCI, (2014), s. 30; DALCI ÖZDOĞAN, s. 200; ŞAHIN CANER, s. 41; TERCIER / PICHONNAZ / DEVELİOĞLU, no. 1626; ARAT, s. 359.

13 KAPANCI, (2019), m. 166, no. 118. Bu üç duruma, zamanaşımı def'inin sadece buna daya- 
- Zamanaşımının işlemeye başlamasında:

Mesela haksız fiilde zarar gören, fiili, zararı ve sorumlulardan birini öğrenmişse, öğrendiği kişi yönünden 2 yıllık zamanaşımı süresi işlemeye başlar. Fakat zarar gören, zarara yol açan diğer müteselsil sorumluyu henüz öğrenememişse; onun için 2 yıllık zamanaşımı süresi başlamaz ${ }^{14}$.

- Zamanaşımının durmasında:

Zamanaşımının durmasına neden olan sebepler kişisel olup, diğer müteselsil borçluları etkilemez ${ }^{15}$. Mesela bir önceki örnekte, sorumlulardan biriyle arasında evlilik ilişkisi bulunan zarar gören için zamanaşımının durması, sadece eşi olan sorumlu için geçerliyken, diğer müteselsil sorumlular için zamanaşımı süresi işlemeye devam eder.

- Zamanaşımı süresinin uzunluğunda:

Müteselsil borçluluk farklı hukuki sebeplere dayandığında, alacaklının her bir müteselsil borçluya yönelik talebinin bağlı olduğu zamanaşımı süresi de diğerinden farklı olabilir. Bu durum şu örnekte açıkça ortaya çıkmaktadır:

(S)atıc1, sattığı malzemeleri (A)lıcıya (Ç)alışanı aracılığıyla teslim etmiştir. Fakat (Ç), gördüğü işle fonksiyonel bağlı bulunan, kusurlu ve hukuka aykırı fiiliyle teslim sırasında alıcıya zarar vermişse, bu zarardan (S)'nin ve (Ç)'nin sorumlu olmasına ilişkin zamanaşımı süreleri farklıdır. Zamanaşımı süresi (Ç) açısından haksız fiil hükümlerine göre 2, 10 ve fiil suç teşkil ediyorsa ceza zamanaşımı süresine bağlıyken; (S) açısından adam çalıştıranın sorumluluğu hükümlerine göre 2-10 yıllık, ifa yardımcısının sorumluluğu hükümlerine göre ise 10 yıllık zamanaşımı süresine bağlıdır.

nan veya bundan vazgeçen müteselsil borçlu için hüküm doğuracağını da eklemek suretiyle, bu farklılık noktalarını dört olarak açıklamak da mümkündür. Bkz. TUTUMLU, s. 111.

14 TEKINAY / AKMAN / BURCUOĞLU / ALTOP, s. 718; KAPANCI, (2014), s. 262; DALCI ÖZDOĞAN, s. 200.

15 TEKINAY / AKMAN / BURCUOĞLU / ALTOP, s. 313; ERDEM, (2010), s. 343; KAPANCI, (2014), s. 157; ŞAHİN CANER, s. 252; NOMER, (2015), s. 419, no. 24; DALCI ÖZDOĞAN, s. 201; YAĞCIOĞLU, s. 234.

Bu yönde: Yargitay 21. HD, 26.02.2018, E. 2016/11976, K. 2018/1726 (www.kazanci.com, erişim: 01.07.2020). 


\section{MÜTESELSİL BORÇLULAR ARASINDAKİ (İÇ) İLISŞKİ}

\section{A. Genel Olarak Rücu Hakkı ve Halefiyetle İlişsisi}

Müteselsil borçluların kendi arasındaki hukuki ilişki incelenirken, öncelikle rücu kavramının açıklanması gerekir.

"Rücu hakkl, bir başkasının nihai olarak üstlenmesi gereken yükü geçici olarak üstlenen başka bir kişinin, geriye dönerek ona başvuruda bulunması ve oluşan geçici durumun giderilmesinde kullanılan bir araçtır." ${ }^{16}$.

Geçici olarak borcun tamamını / bir kısmını ifa etmiş olan borçlunun rücu hakkını kullanılması sayesinde, iç ilişkide bozulan dengenin sağlanması amaçlanır ${ }^{17}$.

Rücu hakkının genel olarak iki temele dayanabileceği kabul edilmektedir ${ }^{18}$ :

1. Kanunun bu yönde açık bir imkân tanımasıyla.

2. Taraflar arasındaki hukuki ilişki nedeniyle bu imkânın doğmasıyla.

Buna göre Kanun, bazı durumlarda ifada bulunan kişinin başkalarına rücu etmesine imkân tanımıştır. Mesela, kamu hizmetinin kötü ifası nedeniyle zarar gören kişinin zararının idare tarafından tazmininden sonra idarenin, kişisel kusuru bulunan kamu görevlisine rücu etmesi mümkündür (Anayasa 40 / III, 129 / V). Başka bir örnek 5510 sayılı Sosyal Sigortalar ve Genel Sağlık Sigortası Kanunu'ndan verilebilir. Bu Kanunun 21. maddesine göre, iş kazası veya meslek hastalığı işverenin kastından veya iş güvenliği mevzuatına aykırı davranışından kaynaklanmışsa, SGK tarafından sigortalıya veya haleflerine yapılan ödemelerin bir kısmı işverene rücu edilebilir. Aynı şekilde bu zarar, üçüncü kişilerin kusurlarından kaynaklanmışsa, kurum hak sahiplerine yaptığı ödemenin bir kısmını bu kişilere rücu edebilir ${ }^{19}$. Bu

16 KAPANCI, (2014), s. 355. Benzer tanımlar için bkz. NOMER, (2011), s. 250.

17 GAUTSCHI, s. 82; BUCHER, s. 496; ANTALYA, s. 667; KAPANCI, (2014), s. 387; ALTAY, s. 395; DALCI ÖZDOĞAN, s. 84; ŞAHİN CANER, s. 252; YAĞCIOĞLU, s. 245; AŞIK, s. 31.

18 Bu ayrım için bkz. TERCIER / PICHONNAZ / DEVELIOĞLUU, no. 1636; KAPANCI, (2014), s. 61, dn. 275 ve özellik s. 356. Benzer ayrım için bkz. NOMER, (2011), s. 250; NOMER, (1997), s. 248; KILIÇOĞLU, (2014), s. 505.

19 YHGK, 19.06.2015, 2013/10/2281 E, 2015/1727 K.: Bu karara göre SGK'nun kusurlu kişilere yönelik rücu talebinde müteselsil sorumluluk söz konusu olmaz. (www.kazanci.com.tr, erişim: 01.07.2020). 
konuyla ilgili verilebilecek diğer örnek, 2330 sayılı Nakdi Tazminat ve Aylık Bağlanması Hakkında Kanun gereğince hak sahiplerine İçişleri Bakanlığınca yapılan yardımın, bakanlıkça sorumlulara rücu edilmesidir ${ }^{20}{ }^{21}$.

Bazı durumlarda ise, rücu hakkı taraflar arasındaki hukuki ilişkiden kaynaklanır. Buna göre taraflar arasındaki özel bir hukuki ilişki (çoğunlukla -bir adi ortaklık, vekâlet ya da iş sözleşmesi gibi- bir sözleşme veya vekâletsiz iş görme ya da sebepsiz zenginleşme) nedeniyle, borçluların, yapılan ifanın belli bir kısmını veya tamamını üstlenmesi / karşılaması gerekebilir ${ }^{22}$. Doktrinde bazı yazarlarca "özel rücu hakkl" olarak nitelenen ${ }^{23}$ bu rücu hakk1, alacaklı ile müteselsil borçlular arasındaki asıl borç ilişkisinden tamamen bağımsız, müteselsil borçlular arasındaki hukuki ilişkiden doğan yeni bir borçtur. $\mathrm{Bu}$ borç, müteselsil borçlulardan birinin yaptığı ifayla kendisine (halef olarak) intikal eden asıl borç değildir² ${ }^{24}$.

Konumuz olan müteselsil borçlular arası rücu ilişkisi, kanaatimce kanundan değil, doğrudan müteselsil borçlular arasındaki hukuki ilişkiden

Bu paragrafta verilen örneklerde SGK'nun veya idarenin, sorumlularla birlikte müteselsil borçluluğu söz konusu olmadığından, bunlara ilişkin rücu zamanaşımı sorunu, konumuzun kapsamı dışındadır. Fakat kısaca belirtelim ki, 5510 sayılı Kanuna göre açılacak olan rücu davaları aynı Kanunun 93 / III hükmüne göre 10 yıllık zamanaşımı süresine bağlanmıştır: "Bu Kanuna dayanılarak Kurumca açılacak tazminat ve rücû davaları, on yıllık zamanaşımına tâbidir. Zamanaşımı tarihi; rücû konusu gelir ve aylıklar bakımından Kurum onay tarihinden, masraf ve ödemeler için ise masraf veya ödeme tarihinden itibaren başlar."

Fakat doktrinde SGK'nun müteselsil borçlu kategorisine dâhil edildiği de görülmektedir: NOMER, (2015), s. 205; NOMER, (1997), s. 252; NOMER, (2011), s. 253; YAĞCIOĞLU, s. 365 .

20 YHGK, 23.02.2000, 4-130 / 124 sayılı kararında, haksız fiil sonucu ölen emniyet görevlisine 2330 sayılı Kanun gereğince İçişleri Bakanlığının yaptığı ödeme için, bakanlığın haksız fiil sorumlusuna rücu edilebileceği kabul edilmiştir. Karar için bkz. KILIÇOĞLU, (2014), s. 460, dn.526. Bakanlığı müteselsil borçlu olduğu görüşünde: NOMER, (2015), s. 204.

21 Örnek olarak verdiğimiz bu durumlarda, rücu hakkı halefiyetle güçlendirilmiş değildir. Bkz. DALCI ÖZDOĞAN, s. 119.

22 TEKINAY / AKMAN / BURCUOĞLU / ALTOP, s. 314; ÖZEN, s. 1452.

23 ÖZEN, s. 1452; KAPANCI, (2019), m. 167, no. 2; KAPANCI, (2014), s. 357 ve özellikle s. 480; KAPANCI, (2019), m. 61-62, no. 27; YAĞCIOĞLU, s. 251 vd; Bu kavramı reddeden görüşte: DALCI ÖZDOĞAN, s. 86, dn. 257.

${ }^{24}$ KILIÇOĞLU, (1979), s. 13; ANTALYA, s. 668; KAPANCI, (2014), s. 359; NOMER, (2011), s. 250; NOMER, (1997), s. 248; KIRCA, s. 49; DALCI ÖZDOĞAN, s. 93; ŞAHIN CANER, s. 255; TERCIER / PICHONNAZ / DEVELIOĞLU, no. 1635; FRANKO, (Halefiyet II), s. 386; YAĞCIOĞLU, s. 250; ÇELİK, m. 73, no. 12; KURT, s. 140. 
doğar ${ }^{25}$. Müteselsil borçlular arasındaki hukuki ilişki, bir sözleşme ilişkisi olabileceği gibi, bunlar arasında bir sözleşme ilişkisinin bulunmadığı hallerde, vekâletsiz iş görme veya sebepsiz zenginleşme niteliğinde de olabilir.

Türk Borçlar Kanunun müteselsil borçluluğa ilişkin iki ayrı maddesinde rücu hakkından bahsedilmektedir (TBK 62 / II ile TBK 167 / II). Her iki hükümde de rücu hakkının varlığı, müteselsil borçlulardan birinin, iç ilişkideki payından daha fazla bir tutar için alacaklıyı tatmin etmesi halinde mevcut olduğu düzenlenmiştir. Böylece rücu hakkının aslında, doğrudan müteselsil borçlular arasındaki iç ilişkiye bağlandığı görülmektedir.

$\mathrm{Bu}$ sebeple kanaatimce, müteselsil borçlulukta rücu hakkının dayanağ1 kanun olmayıp, doğrudan müteselsil borçlular arasındaki hukuki ilişkidir. Bunun sonucu olarak da müteselsil borçlular arasındaki rücu ilişkisinin bağlı olduğu zamanaşımı süresi belirlenirken, rücu talebinin dayanağının da öncelikle belirlenmesi gerekir. Zira rücu talebi mesela adi ortaklık ilişkisine dayanıyorsa zamanaşımı süresi farklı, iş sözleşmesine dayanıyorsa farklı, sebepsiz zenginleşmeye dayanıyorsa farklı olacaktır. Bu konuda aşağıda ilgili k1sımda incelenecektir.

Müteselsil borçlular arasındaki rücu ilişkisinin dayanağını kanun değil, müteselsil borçlular arasındaki özel hukuki ilişki olarak kabul ettiğimizden, TBK 62 / II hükmünde geçen: "Tazminatın kendi payına düşeninden fazlasını ödeyen kişi, bu fazla ödemesi için, diğer müteselsil sorumlulara karşı rücu hakkına sahip(tir)" ile TBK 167 / II, c.1'de geçen "Kendisine düşen paydan fazla ifada bulunan borçlunun, ödediği fazla miktarı diğer borçlulardan isteme hakkı vardır." ifadeleri bulunmasaydı bile, iç ilişkide rücu, müteselsil borçlular arasındaki özel hukuki ilişkiye dayalı olarak mevcut olabilecekti ${ }^{26}$.

Müteselsil borçlular arasındaki özel hukuki ilişkiye dayanan rücu hakkının kullanılması aşamasında müteselsil borçlunun hukuki konumunun güçlendirilmesi için, payından fazla tutarda ödemede bulunan borçlunun alacaklıya halef olacağı da kabul edilmiştir ${ }^{27}$. Konumuzla ilgili olarak TBK

25 AKINTÜRK, s. 207; KAPANCI, (2019), m. 167, no.1. Müteselsil borçlular arasındaki rücu hakkının kanundan doğduğu görüşünde: DALCI ÖZDOĞAN, s. 87, dn. 257; YAĞCIOĞLU, s. 251; TURANBOY, no. 7.

26 KAPANCI, (2019), m. 167, no. 1.

27 Bu etki, özellikle borç için verilmiş olan teminatlar yönünden hüküm doğurmaktadır. Bkz. FRANKO, Halefiyet II, s. 384.

Konumuzun dışında olmakla birlikte doktrinde bu konuda örnek olarak verilen kanaatimce 
62 / II ve TBK 168 / I'de halefiyet esası açıkça belirtilmiştir. Buna genel rücu hakkı da denilmektedir ${ }^{28}$. Konumuz olan müteselsil borçlulukta, borçlulardan birinin payından fazla bir tutarda ifada bulunması halinde, onun diğer müteselsil borçlulara iç ilişkideki payından fazlası için rücu edebileceği, bu aşamada da alacaklının yerine geçerek, alacaklının halefi olarak bu rücu hakkını kullanabileceği kanunda düzenlenmiş olmaktadır.

Halefiyet, ancak rücu hakk1 varsa söz konusu olabilir. Rücu hakkı bulunsa bile, halefiyet ancak rücu hakkı ölçüsünde söz konusudur. Özel rücu hakkının genel rücu hakkını sınırlandıracağı da kabul edilmektedir ${ }^{29}$. Bu yönüyle halefiyet, özel rücu hakkının yardımcısı, özel rücu hakkının bir fer' isidir ${ }^{30}$. Özel

hatalı anlaşılmaya uygun bir durumun belirtilmesinde yarar vardır.

Payından fazla bir miktarda ifada bulunan müteselsil borçlunun rücu hakkını kullanırken sahip olduğu halefiyet gereğince, asıl borç için verilmiș olan bütün teminatların bu borçluya intikal edeceği belirtilmektedir. Mesela A, B ve C'nin müteselsil borçlu olduğu bir olayda (Ü), tüm müteselsil borçlular lehine bir taşınmazını alacaklıya rehin olarak vermişse ve borcun tamamı (A) tarafından ödenmişse, doktrinde (A)'nın bu ipoteği de halef olarak elde edeceği ileri sürülmüştür. İpotek örneği için: KILIÇOĞLU, (2014), s. 757; OĞUZMAN / ÖZ, (2017), no.1431.

Hatta doktrinde (Ü) kefil olsaydı, yine halef olarak (A)'nın (K)'ya rücu edebileceğini ileri sürenler de bulunmaktadır. Bkz. OĞUZMAN / ÖZ, (2017), no. 1431; DALCI ÖZDOĞAN, s. 97; ŞAHIN CANER, s. 283.

Fakat kanaatimce her iki örnekte de halefiyetin kapsamına, tüm borçluların borcu için verilmiş bulunan kefaletler ile üçüncü kişilerce tüm borçlular lehine verilen ipotekler dâhil olamaz.

Zira asıl borçlunun teminat veren üçüncü kişiye başvurması mümkün değildir. Rehin veren üçüncü kişi veya kefil, borcu ödemek zorunda kalınca, zaten asıl borçlulara rücu hakkına sahiptir (rehin için: TMK 884 / II, kefalet için: TBK 596). Doktrinde verilen örneklerde asıl borçlu, kefile veya rehin verene halef olarak rücu edebilecek; kefil veya rehin veren de bu ödeme sonrasında yine aynı asıl borçlulara rücu edebilecektir. Bunun da anlamsız olduğu açıtır.

Bu sebeple, aslında borcun tamamının müteselsil borçluların biri tarafından ödenmesi halinde, tüm borçlular lehine verilen kefaletler ile üçüncü kişilerce tüm borçlular lehine verilen ipotekler sona ermiş olur. Halefiyetin kapsamına girecek olan teminatlar, sadece belli müteselsil borçlu lehine verilmiş bulunan kefaletler ile rehinlerdir. Bunun yanında rücu edilmek istenen asıl borçlulardan birinin verdiği rehinler de halefiyetin kapsamına girer.

Bu konu ayrı bir çalışmayı hak eden özel bir nitelik taşıdığından, bu aşamada bu açıklamayla yetinmek uygun olacaktır.

28 KAPANCI, (2014), s. 357.

29 TEKINAY / AKMAN / BURCUOĞLU / ALTOP, s. 321; ÖZEN, s. 1461; KAPANCI, (2014), s. 62, s. 357 ve özellikle s. 371; AŞIK, s. 46; NOMER, (1997), s. 250.

30 AKINTÜRK, s. 223, KILIÇOĞLU, (1979), s. 137; KAPANCI, (2014), s. 357 ve s. 390; ŞAHIN CANER, s. 283. Aksi görüşte: DALCI ÖZDOĞAN, s. 99; YAĞCIOĞLU, s. 262. 
rücu hakkının bulunmaması halinde, halefiyet de olmaz ${ }^{31}$. Mesela müteselsil borçlular arasındaki sözleşme ilişkisinde, borcun tamamının iç ilişkide bir borçlu üzerine kalacağı kararlaştırılmışsa, borcun bu kişi tarafından alacaklıya ifası halinde özel rücu yolu kapatıldığından, halefiyete dayalı genel rücu yolu da bulunmayacaktır.

Bu konuda Kapancı'nın verdiği örnek şöyledir: Bankadan kredi almak isteyen B1, bankanın talebi üzerine teminat amaciyla B2'nin müteselsilen borçlu olmasını sağlamışsa, dış ilişkide banka, borcun tamamını B1 veya B2'nin birinden isteyebilir. Bu olayda borcun tamamını B1 öderse, genel rücu hakk1 kapsamında B2'ye başvurup, yaptığ1 ödemenin yarısını karşılamasını isteyebilir (TBK 167 / I-II). Fakat B2, kendisinin gerçekte teminat veren sıfatının bulunduğunu, diğer bir ifadeyle B1 ile arasında, B1'in kredi sözleşmesine teminat sağlama borcunu üstlendiği bir vekâlet sözleşmesinin akdedildiğini iddia ve ispat ederse, bu sözleşme gereğince kendisinin iç ilişkide borca hiç katlanmayacağı kararlaştırıldığından, özel ilişkinin ortadan kaldırdığı rücu hakkı, genel rücu yolunu da tamamen kapatır.

Bu olayda borcun tamamını B2 ödemek zorunda kalmışsa, B1'e yönelik rücu talebinde, iç ilişkiyi iddia ve ispat etmesi halinde, rücu hakkını 1/2'lik kısım için değil, yaptığı tüm ödeme için kullanabilecektir.

Böylece aslında müteselsil borçlular arasındaki halefiyetin, gerçekte doğrudan rücu hakkına bağlı olduğunu kabul etmiş bulunmaktayız.

Halefiyete dayalı genel rücu hakkında başvurunun temeli, alacaklıdan halefiyet yoluyla intikal eden asıl borç ilişsisidir. Zira, burada alacaklıya yapılan ifayla borç sona ermemekte, alacak hakkı, (iç ilişkideki) rücu hakkının bulunduğu ölçüde ifada bulunan müteselsil borçluya intikal etmekte, bu müteselsil borçlu da alacaklının hukuki konumunu elde edip, diğer müteselsil

31 AKINTÜRK, s. 223; KILIÇOĞLU, (1979), s. 74; KAPANCI, (2019), m. 168, no. 7; KURT, s. 140, dn. 15. BUCHER, s. 497; TEKINAY / AKMAN / BURCUOGLU / ALTOP, s. 316 ve özellikle s. 320 vd; NOMER, (2011), s. 250.

Aynı durum, kefalet sözleşmesinde kefilin halefiyeti bakımından da geçerlidir. Bkz. ÖZEN, s. 1461.

Müteselsil borçlunun, ortak ilişkiden doğan savunmayı kusurlu olarak ileri sürmeyip ödemede bulunmak zorunda kalması halinde, onun rücu hakk1 ve bununla paralel olarak halefiyeti de söz konusu olmayacaktır (TBK 164 / II). KILIÇOĞLU, (1979), s. 75; KAPANCI, (2014), s. 373. Bkz. DALCI ÖZDOĞAN, s. 94.

Sigorta sözleşmesinde, rücu hakkı bulunmayan bir halefiyetin bulunduğuna ilişkin görüş için bkz. KILIÇOĞLU, (1979), s. 14; DALCI ÖZDOĞAN, s. 119. 
borçlulara rücu etmektedir. Halef, selefinin hukuki konumunu elde ettiğinden, selefinin haklarına sahip olacak ve onun bağlı olduğu kısıtlamalara tabi olarak hakkını kullanabilecektir ${ }^{32}$.

Mali yükün asıl sorumlular arasında dengelenmesi biçimindeki amaca hizmet eden bu iki imkânın (genel rücu - özel rücu) birbiriyle yarışmalı olarak uygulama alanına sahip olduğu doktrinde kabul edilmektedir ${ }^{33}$. Bunlardan biri kullanılarak amaca ulaşıldığında, diğerinin kullanılma imkânı da ortadan kalkar.

Özel rücu hakkının kapsamı, halefiyete dayalı genel rücu hakkından daha geniş veya dar olabilir ${ }^{34}$.

Halefiyete dayalı genel rücu hakkı, buna başvuran müteselsil borçluya iki temel imkân / kolaylık sağlar ${ }^{35}$ :

1. İspat kolaylı̆̆1:

Halefiyete dayalı rücu hakkını kullanmak isteyen müteselsil borçlu, ilk olarak iç ilişkideki sorumluluk payının Kanunun karine olarak düzenlendiği biçimde olduğunu ileri sürüp, bunu aşan kısma ilişkin ifasının diğer müteselsil borçlular tarafindan kendisine ödenmesini talep edebilir.

Müteselsil borçlular arasındaki hukuki ilişkiye dayalı sorumluluk payının TBK 62 / I ve TBK 167 / I'de belirtilenden daha az olması halinde, davalı bunu iddia ve ispat yükü altındadır.

Halefiyet, buna dayanan müteselsil borçluyu, rücu hakkını varlığı ve miktarı konusundaki (iç ilişkiye dayalı) ispat yükünden ve müteselsil borçlular arasındaki hukuki ilişkiyi iddia ve ispat yükünden kurtarır.

Fakat müteselsil borçlular arasındaki iç ilişkiye dayalı davalının payının, TBK 62 / I ve TBK 167 / I'de belirtilenden daha fazla olması halinde, bunu iddia ve ispat yükü, elbette ki davacıda olacaktır.

\footnotetext{
32 NOMER, (1997), s. 244; DALCI ÖZDOĞAN, s. 96; YAĞCIOĞLU, s. 258.

33 KILIÇOĞLU, (1979), s. 17; NOMER, (2011), s. 251; NOMER, (1997), s. 250; KAPANCI, (2014), s. 358; KAPANCI, (2019), m.61-62, no.27; KAPANCI, (2019), m. 167, no. 4; DALCI ÖZDOĞAN, s. 98.

34 Bu konudaki örnekler için bkz. KILIÇOĞLU, (1979), s. 18; KAPANCI, (2014), s. 367 vd.

35 Karş. KILIÇOĞLU, (1979), s. 69; KAPANCI, (2019), m. 167, no. 1; YAĞCIOĞLU, s. 260; AȘIK, s. 47; NOMER, (1997), s. 249; KURT, s. 140.
} 
Bu yönüyle müteselsil borçlular arasındaki halefiyetin ilk işlevinin ispat kolaylığı olduğu söylenebilir.

2. Teminatların intikali:

Halefiyetin ikinci işlevi, teminatların intikalidir. İntikale elverişli teminatlar, rücu hakkının da teminatını oluşturacaktır.

$\mathrm{Bu}$ açıklamalarımıza göre genel rücu hakkına (halefiyete) dayanmak isteyen müteselsil borçlunun, müteselsil borçluluğun varlığını ve kendisinin iç ilişkideki payından ${ }^{36}$ fazla bir tutarda ifada bulunduğunu kanıtlamasının yanında ayrıca bir başka hususu daha ispat etmesine gerek yoktur ${ }^{37}$. Fakat müteselsil borçluyla arasındaki özel hukuki ilişkiye dayalı rücu hakkını kullanmak isterse, ayrıca bu hukuki ilişkiyi de ispat etmesi gerekir ${ }^{38}$.

Mesela bir iş sözleşmesiyle çalışan işçinin, işini gördüğü sırada üçüncü bir kişiye zarar verdiğini ve bu fiil nedeniyle kusur sorumluluğu bulunan işçi yanında, işverenin de zarar görene karşı adam çalıştıran sıfatıyla TBK 66 hükmüne göre sorumlu olduğunu kabul edelim. Bu olayda işveren, zararın tamamını karşılamışsa, işçiye rücu imkânını iki hukuki yoldan sağlayabilir: 1 . TBK 62 / II gereğince halefiyet, 2. İş sözleşmesine aykırılıktan doğan zararın tazmini ${ }^{39}$.

Halefiyete dayalı genel rücu talebinde uygulanacak olan zamanaşımı süresi ve bunun başlangıcı ile müteselsil borçlular arasındaki iç ilişkiye dayalı rücu hakkının bağlı olduğu zamanaşımı süresi ile başlangıcı farklılık gösterir. Bunların ikisinin ayrı ayrı incelenmesi gerekir. Fakat öncelikle müteselsil borçlular arasındaki payların belirlenmesi konusunda kısa bir açıklama yapılması uygun olur.

\section{B. Müteselsil Borçluların İç İlişkideki Paylarının Belirlenmesi}

Konumuz olan müteselsil borçlulukta, her bir borçlu alacaklıya karş1 borcun tamamından sorumlu olmakla birlikte, borçluların kendi aralarındaki ilişkide borçtan sorumlu olma oranları ayrıca belirlenmelidir.

\footnotetext{
36 İç ilişkideki payın belirlenmesi konusunda bkz. aşa. II, B.

37 FRANKO, Halefiyet I, s. 204; KAPANCI, (2019), m. 168, no. 7, 8.

Aksi görüşteki Dağdelen'e (s. 189) göre, bu ihtimalde özel rücu hakkının varlığının da ispatı gerekir.

38 KAPANCI, (2014), s. 61, s. 359 ve s. 370.

39 İş sözleşmesinde işçinin işi özenle icra etme borcu bulunmaktadır (TBK 396/ I). İşçi işi özenle icra etme borcuna aykırı davranıp işverene zarar verirse, bu zararı sözleşmeye aykırılık hükümlerine göre tazmin etmekle yükümlüdür (TBK 400 / I).
} 
Müteselsil borçluların iç ilişkideki sorumluluk paylarının tespiti çalışmamızın kapsamında değildir ${ }^{40}$. Fakat kısaca belirtelim ki, gerek haksız fiilde, gerekse de haksız fiil dışı müteselsil borçluluk hallerinde iç ilişkideki paylaşım oranları, varsa müteselsil borçluların akdettikleri sözleşmeye göre, yoksa Kanunda belirtilen ilkelere göre belirlenir. Buna göre müteselsil borçluların rücu talebine ilişkin davada, taraflarca, aralarındaki sözleşme ilişkisine göre daha farklı bir biçimde payların belirlenmesinin gerektiği tarafların herhangi birince iddia ve ispat edilmediği sürece iç ilişkideki paylar haksız fiile dayalı müteselsil sorumlulukta TBK 62 / I'de belirtilen ilkelere göre hâkim tarafından belirlenecek olup, haksız fiil dışındaki müteselsil borçluluk hallerinde TBK 167 / I gereğince (işin niteliğinden aksi anlaşılmadıkça) eşit olarak değerlendirilecektir ${ }^{41}$. Bu hükümlerden ayrı bir oranın uygulanması gerektiğini iddia eden, bunu usulüne uygun olarak ispat külfeti altındadır.

Haksız fiil alanında da, tazminatın müteselsil borçlular arasında nasıl paylaştırılacağına, hangi müteselsil borçlunun iç ilişkide bu tazminatın ne kadarını üstleneceğine ilişkin bir sözleşme varsa, iç ilişkideki paylaşım bu sözleşmeye göre yapılır ${ }^{42}$. Fakat müteselsil borçlular arasında bu yönde bir sözleşme yoksa, aynı zarardan birden çok kişinin sözleşme dış1 sorumluluğunda, müteselsil borçluların iç ilişkideki paylaşım oranı TBK 62 / I hükmüne göre somut olayın bütün durum ve koşulları ile sorumluların kusur ağırlığı ve yarattıkları tehlikelilik derecesine göre hâkimce belirlenir ${ }^{43}$.

Meseleyi bir örnekle açılayalım:

(A) ve (B)'den oluşan adi ortaklığın işlettiği bir havai fişek fabrikasının faaliyetinden tehlike sorumluluğu hükümlerine doğan tipik tehlike gerçekleşir ve üçüncü kişiler zarar görürse, (A) ve (B) bu zarardan müteselsilen sorumlu olur. (A) ile (B) arasındaki adi ortaklık sözleşmesinde, bu işletmenin işletilmesinden doğacak zararların iç ilişkide tamamen (B)'nin sorumluluğunda olacă̆ 1 yönünde bir hüküm varsa, iç ilişkideki paylaşım konusunda bu hükme göre değerlendirme yapılması gerektiği açıktır.

40 Bkz. DALCI ÖZDOĞAN, s. 99 vd.

41 Bkz. ve karş. TEKINAY / AKMAN / BURCUOĞLU / ALTOP, s. 315; OĞUZMAN / ÖZ, (2017), no. 1410; KAPANCI, (2019), m. 61-62, no. 28; KILIÇOĞLU, (2014,) s. 754; ŞAHIN CANER, s. 257; TERCIER / PICHONNAZ / DEVELIOĞLU, no. 1642; NOMER, (2015), s. 202; ÇAVUŞOĞLU IŞINTAN, s. 502; YAĞCIOĞLU, s. 380.

42 DALCI ÖZDOĞAN, s. 100.

43 Bu konuda bkz. EREN, s. 928; KAPANCI, (2014), s. 522; KAPANCI, (2019), m. 61-62, no. 29 vd; DALCI ÖZDOĞAN, s. 101; GÜRPINAR, s. 282. 
Benzer bir örnek iş sözleşmesinden verilebilir. İş sözleşmesinde, işçinin hafif kusurlu olarak zarar vermesi halinde, işverene karşı sorumlu tutulmayacağ 1 yönünde geçerli bir sorumsuzluk hükmü varsa ve işçi, hafif kusurlu bir fiille işini ifa ederken üçüncü kişiye bir zarar vermişse, iş̧̧i bu zarardan zarar görene karşı haksız fiil hükümlerine göre, işveren ise adam çalıştıran sıfatıyla TBK 66 hükmüne göre sorumludur. Bunların sorumluluğu da müteselsildir. Eğer zararın iç ilişkide paylaşılmasında taraflar arasındaki sözleşme hükmü görmezden gelinirse, işveren ödediği tazminat için işçiye rücu edebilecektir. Fakat haksız fiile dayalı rücu ilişkilerinde de taraflar arasındaki sözleşmesel ilişkinin dikkate alınması gerekir. Bu sebeple bu verilen örnekte işveren, iç ilişkide iş̧̧iye rücu edemeyecektir.

Fakat bu örneklerde belirtilenin aksine haksız fiil nedeniyle müteselsilen sorumlu olanlar arasında bu yönde bir sözleşme yoksa veya böyle bir sözleşme hükmünün varlığı iddia ve ispat edilemezse, bu zararın iç ilişkide nasıl paylaşılacağı TBK 62 / I hükmüne göre hâkimce belirlenir.

$\mathrm{Bu}$ konuda son olarak belirtilmesi gereken bir konu da, iç ilişkideki sorumluluğun dağılımı konusundaki TBK 62 / I hükmünün yasal istisnalarının olabileceğinin gözden kaçırılmamasıdır. Mesela KTK 89'da iç ilişkideki paylaşım düzenine ilişkin bir hüküm bulunmaktadır.

Aynı şekilde haksız fiil hukuku alanı dışındaki müteselsil borçluluk hallerinde de iç ilişkideki paylaşım oranları, yine varsa müteselsil borçlular arasındaki sözleşme hükümlerine göre belirlenir. Müteselsil borçlular arasında bir sözleşme yoksa veya sözleşmede bu konuda bir hüküm yoksa, borçlular arasındaki hukuki ilişkinin özelliğinden aksi anlaşılmadıkça, iç ilişkideki paylar eşittir ${ }^{44}$.

Görüldüğü gibi, gerek sorumluluk hukuku alanında, gerekse de sorumluluk hukuku dişı alanda müteselsil borçlulukta iç ilişkideki paylar, öncelikle müteselsil borçluların iradesine göre belirlenir. Bu yönde bir irade ortaya konulmamışsa müteselsil borçluların iç ilişkideki payları, haksız fiil alanında TBK 62 / I hükmüne göre hâkimce belirlenecek oranda; sorumluluk hukuku dışı müteselsil borçlulukta ise TBK 167 / I hükmüne göre eşit olarak paylaşılacaktır.

Gerek müteselsil borçlular arasındaki hukuki ilişkiye göre belirlenen, gerekse de doğrudan Kanun hükümlerine göre belirlenen bu iç ilişkideki

44 Bu konuda bkz. EREN, s. 1354; ACAR, (2010), no. 61 vd; AYAR / ENGİN, s. 1294. 
payından fazla miktarda bir tutar için alacaklıyı tatmin eden müteselsil borçlu, bu payını aşan kısım için diğer müteselsil borçlulara dönüp, bu kısmın kendisine ödenmesini talep edebilir. Bunu isterken de, halefiyet ayrıcalığından yararlanir.

Müteselsil borçlu sayısı en az üçse ve borcun tamamını borçlulardan biri ifa etmişse, diğer iki müteselsil borçluya rücu hakkı, kural olarak müteselsil değil, paylı bir borçluluk niteliği taşır (TBK 167 / II, c.2). Diğer bir ifadeyle rücu aşamasında teselsül söz konusu olmaz. İç ilişkide borçlular, payları oranında sorumlu tutulurlar ${ }^{45}$. Fakat bu hüküm emredici olmayıp, müteselsil borçlular arasındaki sözleşmede aksine hükümler getirilebilir.

\section{MÜTESELSILL BORÇLULAR ARASINDAKİ HUKUKİ İLIŞKIYYE DAYALI ÖZEL RÜCU HAKKININ TABİ OLDUĞU ZAMANAŞIMI SÜRESI}

\section{A. Genel Olarak}

Müteselsil borçlulardan birinin dış ilişkide alacaklıya ifada bulunması sonrasında, müteselsil borçlular arasında iç hesaplaşma yapılacaktır. Bu iç hesaplaşma, müteselsil borçlular arasındaki hukuki ilişkiye dayanır. Müteselsil borçlular arasındaki iç ilişkide, bu iç ilişkiye göre belirlenmesi gereken sorumluluk payından fazla ödeme yapanın diğerlerine başvurabileceğine ilişkin hükümler bulunabilir. İşte bu hukuki ilişkiye göre, payından fazla ifada bulunan müteselsil borçlu, diğer müteselsil borçlulara, temelini müteselsil borçlular arasındaki hukuki ilişkiden alan rücu talebini ileri sürebilir.

Müteselsil borçlular arasındaki iç ilişkiye dayalı bu rücu hakkının, halefiyet yoluyla intikal eden hakla bir ilişkisi yoktur. Bu rücu hakkı, doğrudan (payından fazla bir miktarda) ifayla doğar ve dayanağını müteselsil borçlular arasındaki hukuki ilişkiden alır.

Özel rücu talebinden doğan alacak, kural olarak ifayla birlikte muaccel olur ${ }^{46}$. Bu alacağın bağlı olduğu zamanaşımı süresi de, alacaklı ile müteselsil borçlular arasındaki hukuki ilişkiden bağımsız olarak, müteselsil borçlular arasındaki hukuki ilişkiye göre belirlenir ${ }^{47}$. Helefiyete bağlı alacak

45 Bkz. KAPANCI, (2014), s. 60, s. 392; YAĞCIOĞLU, s. 73.

46 KAPANCI, (2014), s. 360.

47 GAUTSCHI, s. 146 vd; GAUCH / SCHLUEP / EMMENEGGER, no. 3743; KILIÇOĞLU, (1979), s. 13; KAPANCI, (2014), s. 360, s. 540. 
zamanaşımına uğramış olsa bile, özel rücu hakkı (zamanaşımına uğramamışsa) ileri sürülebilir ${ }^{48}$. Rücu alacağının bu özelliği nedeniyle, zamanaşımının dış ilişkide bir müteselsil borçluya karşı kesilmesi, iç ilişkiye dayalı rücu alacağı için bir etki yaratmaz ${ }^{49}$.

Müteselsil borçlular arasındaki hukuki ilişki çeşitli biçimlerde karşımıza çıkabilir ${ }^{50}$. Bunların detaylı olarak incelenmesi çalışmamızın kapsamını aşmaktadır ${ }^{51}$. Fakat kısaca belirtelim ki, müteselsil borçlular arasında ya bir sözleşme ilişkisi vardır, ya da yoktur. Aşağıda bu temel çıkış noktası dikkate alınarak değerlendirmeler yapılacaktır ${ }^{52}$.

\section{B. Müteselsil Borçlular Arasında Bir Sözleşme İlişkisinin Bulunması Durumunda Rücu Talebi}

Müteselsil borçlular arasında bir sözleşme ilişkisinin bulunması halinde, borcun sebebi haksız fiil olsa bile, müteselsil borçlular arasındaki iç ilişkide rücu, bu sözleşme hükümlerine göre gerçekleşir ${ }^{53}$. Bu durumda TBK 73 hükmü uygulanmaz.

Müteselsil borçlular arasındaki sözleşme çok çeşitli biçimde karşımıza çıkabilir. Adi ortaklık, vekâlet sözleşmesi, iş sözleşmesi, sigorta sözleşmesi $\mathrm{vs}^{54}$. Müteselsil borçlular arasındaki sözleşme ilişkisinin hukuki niteliğinin

48 NOMER, (2011), s. 251; ÇELİK m. 73, no. 17.

49 DALCI ÖZDOĞAN, s. 223; YAĞCIOĞLU, s. 390.

50 Bu konuda 818 sayılı Kanun döneminde savunulan görüşler ve farklı kararlar için bkz. ERDEM, (2010), s. 107 vd; ÇELİK, m. 73, no. 5; KURT, s. 142 vd.

51 Çalışmamızın kapsamı dışında tuttuğumuz bu konuda bkz. KAPANCI, (2014), s. 480 vd; KILIÇOĞLU, (1979), s. 16.

52 Bu yönde: ERDEM, (2010), s. 114.

53 TEKINAY / AKMAN / BURCUOĞLU / ALTOP, s. 1046; OĞUZMAN / ÖZ, (2017), no. 862; ŞAHINN CANER, s. 123; ERDEM, (2010), s. 115. Müteselsil borcun sözleşme ilişkisine dayanması halinde bu yönde: ÇELIKK, m. 73, no. 7.

54 Bu dayanak kira sözleşmesi bile olabilir. Mesela (A)'nın 1/5, (B)'nin ise 4/5 oranında paylı malik olduğu bir taşınmazın malikleri akdettikleri sözleşmede, taşınmazın tamamının (B) tarafından kullanılacağı, taşınmazın tüm bakımının da bu kişi tarafından yürütüleceği kararlaştırılmış olsun. Bu olayda taşınmazdaki bakım eksikliği nedeniyle zarar gören üçüncü kişi karşısında (A) ve (B) müteselsilen sorumludur. (A), zarar görenin tüm tazminat talebini yerine getirdikten sonra, (B)'ye rücu edebilir. Bu rücu talebi, onlar arasındaki sözleșme ilişkisine dayanır. Rücu talebi, (B)'nin borca aykırı davranışına dayandığından ve (A) ile arasında bu olayda bir kira sözleşmesi bulunduğundan, (B)'nin (A)'ya karşı sorumluluğu 10 yıllık zamanaşımı süresine bağlı ve iç ilişkideki paylar, TBK 62 / I hükmüne göre değil, müteselsil borçlular arasındaki sözleşme hükümlerine göre belirlenir. 
tespiti bu çalışmanın kapsamının dışında, başlı başına incelemeyi hak eden bir konu niteliğindedir ${ }^{55}$. Aşağıda müteselsil borçlular arasında varlığı tespit edilen sözleşme ilişkilerinden uygulamada sıklıkla görülen bazılarındaki rücu sorunu incelenecektir.

\section{Adi Ortaklık:}

TBK 638 / III gereğince “Ortaklar, birlikte veya bir temsilci aracılığı ile, bir üçüncü kişiye karşı, ortaklık ilişskisi çerçevesinde üstlendikleri borçlardan, aksi kararlaştırılmamışsa müteselsilen sorumlu olurlar." Bu hükme göre ortaklar, ortaklığın borçlarından müteselsilen sorumludur.

TBK 627 / I gereğince "Ortaklardan birinin ortaklık işleri için yaptı̆̆ giderlerden veya üstlendiği borçlardan dolayı diğer ortaklar, ona karşı sorumlu olurlar; ...."

Bu hükme göre de, ortaklığın borcunu, müteselsil borçluluk hükümlerine göre alacaklıya ödemiş bulunan ortak, TBK 627 / I hükmüne göre ortaklık işi için yaptığı giderin iadesi zımnında rücu hakkını kullanabilecektir ${ }^{56}$. Böylece rücu hakkının temelinin, bu ortaklık sözleşmesi olduğunu tespit etmiş bulunmaktayı.

Rücu hakkının hangi miktar için kullanılabileceği de yine ortaklar arasındaki hukuki ilişkiye göre belirlenir. Bu durumu bir örnekle açıklayalım:

(A) ve (B)'den oluşan adi ortaklık, bir havai fişek fabrikası işletiyor olsun. İşletmedeki tipik tehlike gerçekleşmiş ve patlama gerçekleşmişse, bu patlama sırasında yaralanan (I)'nin zararından, (A) ve (B) müteselsilen sorumludur. (A) bu zararın tamamını ödemek zorunda kalmışsa, TBK 627 / I'e dayalı rücu talebiyle, yaptığ 1 giderin (B)'nin ortaklık payı ölçüsünde kendisine ifasını talep edebilir.

Fakat bu olayda (B) yönetici ortaksa, bu işletmenin bütün kontrolünü ve denetimini kendisi sağlıyorsa ve onu gerekli hiçbir denetimi yapmaması ve alması gerekli güvenlik önlemlerini almaması nedeniyle bu kaza meydana gelmişse, bu durumda tazminatın tamamını ödemek zorunda kalan (A), TBK 628 / II gereğince bu zararın tamamının karşılanmasını da talep edebilir.

\footnotetext{
55 Müteselsil borçlular arasında kural olarak her durumda bir adi ortaklık ilişkisinin kurulduğunun söylenebileceği görüşünde: KAPANCI, (2014), s. 496.

56 KAPANCI, (2014), s. 498; ERDEM, (2010), s. 115.
} 
Böylece müteselsil borçlular arasında bir adi ortaklık ilişkisinin bulunduğu hallerde, alacaklıya karşı borcun tamamını ifa etmiş bulunan müteselsil borçlu ortağın, adi ortaklığa ilişkin hükümlere göre diğer ortaklara rücu edebileceği, rücu alacağının ortaklık sözleşmesi hükümleri gereğince 5 y1llık zamanaşımına süresine tabi olduğu (TBK 147 / I, b.4), bu rücu talebinin ödemenin yapılmasıyla muaccel olacağı ortaya çıkmaktadır.

\section{Vekâlet sözleşmesi:}

Müteselsil borçluluk, vekilin, müvekkilin bir işini görmek amacıyla müteselsil borçlu hale gelmesine ilişkin (müvekkil - vekil arasındaki) anlaşmadan kaynaklıyorsa, rücu ilişkisinin bu sözleşme hükümleri kapsamında çözümlenmesi gerekir. Mesela (A) bir ev kiralamak istemektedir. Fakat kiraya veren $(\mathrm{K})$ 'nın, ancak bir sigortalı çalışanla birlikte kiracı olarak imzalaması halinde bu evi (A)'ya kiraya verebileceğini söylemesi üzerine (B), (A)'nın bu evi kiralayabilmesini sağlamak amacıyla (A) ile birlikte kiracı olarak bu kira sözleşmesini imzalamışsa ve sözleşmede kiracıların müteselsil borçlu olacağ 1 yönünde bir hüküm bulunması halinde, (B)'nin müteselsil borçluluğunun temelinin vekâlet sözleşmesine dayandığı söylenebilir ${ }^{57}$.

$\mathrm{Bu}$ olayda (A) müvekkil (işi görülen), (B) ise vekil (iş gören) konumundadır. Müteselsil borçluluk hükümleri gereğince (B) kira borcunun tamamını ödemek zorunda kalmışsa, bu vekâlet sözleşmesi hükümleri gereğince (A)'ya rücu edebilir. Bu durumda rücu talebinin dayanağ 1 , TBK 510 / I hükmüdür. (B) bu talebini TBK 147 / I, b.5 gereğince 5 yıllık zamanaşımın süresine tabidir.

\section{3. İşs sözleşmesi:}

Bir işçinin kusurlu fiiliyle üçüncü kişiye zarar vermesi halinde bu zarardan, işçi haksız fiil hükümlerine göre, işveren ise (koşulları varsa) adam çalıştıranın sorumluluğu hükümlerine göre dış ilişkide TBK 61 gereğince müteselsilen sorumludur. İşverenin tazminatın tamamını tek başına ödemesi halinde, işçiye yönelik rücu talebi, aslında iş̧̧i ile işveren arasındaki iş sözleşmesinden işçi için doğan borca aykırılık hükümlerine dayanır. İş sözleşmesinde işçi, TBK 396 / I gereğince "Iş̧̧̧i, yüklendiği işi özenle yapmak ve işverenin haklı

KAPANCI, (2014), s. 483. Bkz. TEKİNAY / AKMAN / BURCUOĞLU / ALTOP, s. 314.

Aynı durum, teminat amaciyla mevcut borca sonradan katılma halinde de geçerlidir. Mesela (Ü), (A) ile (B) arasında mevcut olan borca, teminat sağlamak amaciyla müteselsil borçlu hale getirilir ve borcun tamamını ödemek zorunda kalırsa da aynı durum karşımıza çıkabilecektir. 
menfaatinin korunmasinda sadakatle davranmak zorundadır." Ve yine ayn kanunun 400 / I hükmüne göre "Iş̧̧̧i, işverene kusuruyla verdiği her türlü zarardan sorumludur." Bu sebeple, işçinin işini kusurlu olarak özensiz icra etmesinden üçüncü kişinin uğradığı zararı işveren ödemek zorunda kalmışsa, bu hükümlere göre işçiye başvurup, kendi payını aşan kısmın ifasını talep edebilir.

İş sözleşmesinde, işçinin işi özenle icra etme borcuna aykırılıktan doğan talepler ile işverenin işçiyi koruma borcuna aykırılıktan doğan talepler 10 yıllık genel zamanaşımı süresine tabidir ${ }^{58}$. Bu sebeple işveren, ödediği tazminattan işçinin iç ilişkideki payına düşen kısmı ödeme tarihinden itibaren 10 yıllık zamanaşımı süresi içinde ileri sürebilir.

\section{Sigorta Sözleşmesi:}

Sigorta sözleşmesine dayalı rücu hakkı konusu incelenirken, öncelikle bazı genel hususların açıklanmasında yarar vardır.

Bilindiği gibi sigorta sözleşmeleri sigorta konusu olan menfaate göre meblağ (can) sigortaları (TTK 1478 - 1520) ve zarar sigortaları (TTK 1453 - 1486) olarak ikiye ayrılır ${ }^{59}$. Meblağ (can) sigortalarında sigortalı, hem sigorta bedelini sigortacıdan, hem de uğradığı zararın tazminini, koşulları varsa sorumludan yığılmalı olarak talep edebilir ${ }^{60}$. Bu yönüyle meblağ sigortalarında kümülatif alacak söz konusudur ${ }^{61}$. Bu sebeple meblağ sigortalarında sigortacının müteselsil borçluluğu söz konusu olmadığından, buna bağlı olarak halefiyeti de söz konusu olmaz. Diğer bir ifadeyle, konumuz olan müteselsil borçlulukta rücu zamanaşımı sorunu, meblağ sigortalarında sigortacının müteselsil borçluluğu bulunmadığından, ortaya çıkan bir sorun değildir.

ERDEM, (2019), m. 147, no. 10.

59 Bkz. KAYIHAN, s. 1596.

60 OĞUZMAN / ÖZ, (2017), no.1338; DALCI ÖZDOĞAN, s. 117; KAYIHAN, s. 1600.

${ }^{61}$ Hayat sigortası yönünden bu durum TTK 1491 / III hükmünde şöyle belirtilmiştir: “(3) 1472 nci madde hükmü hayat sigortalarında uygulanmaz. Hayat sigortası sözleșmesi gereği, sigorta şirketinden kararlaştırılan sigorta bedelini tahsil eden sigorta ettiren ve mirasçıları ile rizikoya muhatap olan kişilerin mirasçılarının, rizikonun gerçekleşmesine neden olan üçüncü kişiye karșı sahip olduğu tazminat alacağını sigorta șirketine temlik etmeleri geçersizdir." Görüldügü gibi bu hükümle, halefiyetin söz konusu olmayacağı, bu sebeple hem sigorta şirketinden sigorta bedelinin, hem de sorumlulardan tazminatın talep edilmesinin mümkün olduğu açıkça belirtilmiş olmasının yanında, tazminat alacağının sigorta şirketine devri dahi açıkça yasaklanmıştır. 
Zarar sigortaları ise kendi içinde mal sigortası ve sorumluluk sigortası olarak ikiye ayrilır.

Mal sigortasında sigorta şirketi, mal zarar gördüğünde, ortaya çıkan zararı gidermeyi sigortalıya üstlenir (TTK 1459). Sigortacının bu sorumluluğunun doğmasında, bir üçüncü kişinin sorumluluğunun bulunup bulunmaması veya (varsa) sorumluluğunun kapsamı önemsizdir. Mesela bir aracın kasko sigortası yapılmasında, aracın camı kendiliğinden çatlasa bile, (bu risk teminat dâhilindeyse) sigorta şirketi bu zararı gidermekle yükümlüdür. Fakat bu cam kırılmasına bir üçüncü kişi, kusurlu ve hukuka aykırı olarak neden olmuşsa, onun da bu zararı giderme borcu bulunmaktadır.

Konumuz olan müteselsil borçluluktaki rücu zamanaşımı sorununun incelenmesinde öncelikle tespiti gereken husus, mal sigortacısının, mala zarar verdiği için sorumluluğu bulunan üçüncü kişiyle birlikte müteselsil borçlu olup olmadığının tespitidir. Zira mal sigortacısı müteselsil borçlu sayılırsa, müteselsil borçlulukla ilgili TBK 61-62 ve 162 - 168 hükümleri de uygulama alanı bulacak ve özellikle sigortacının halefiyetine ilişkin TTK 1472 ile müteselsil borçlunun rücu ve halefiyetine ilişkin TBK 62 / II ile 167 / II ve 168 / I hükümlerinin uygulanması konusunda bir tartışma ortaya çıkacaktır. Fakat mal sigortacısı, zarardan sorumlu olan kişiyle birlikte müteselsil borçlu sayılmazsa, TBK 62 / II ve 162 - 168 hükümleri uygulama alanı bulamayacak, doğrudan ve sadece TTK 1472 hükmü uygulanacaktır.

Kanaatimce mal sigortalarında sigortacının borcu ile zarar verenin borcu aynı borç olmadığından, bunlar müteselsil borçlu sayılamaz ${ }^{62}$. Borçların ayniyeti olmadığından, bunlar müteselsil borçlu sayılamaz ve TBK 62 / II ve 162 - 168 hükümlerine göre sorumlulukları söz konusu olmaz ${ }^{63}$. Bu sebeple mal sigortacısının zararı karşılaması halindeki hukuki durumu TTK 1472 gereğince sigortalıya halef olmaktan ibarettir ${ }^{64}$.

Aksinin kabulü tamamen haksız sonuçların doğmasına da neden olur. Şöyle ki: mesela bir kişi hafif kusurlu olarak başkasının, değeri 100 TL olan malına zarar vermiş, malın tamamen telef olmasına neden olmuşsa, onun

62 Bu yönde: KAPANCI, (2019), m. 61-62, no. 35.

Nomer mal sigortasında sigortacıyı müteselsil borçlu saymaktadır. NOMER, (2011), s. 252; NOMER, (1997), s. 256. Bu yönde: KOLLER, s. 1209.

${ }_{63}$ Mal sigortasında sigortacı ile zarar verenin müteselsil borçlu olmamasının bir sonucu olarak, zamanaşımı sigortacıya veya zarar verene karşı kesilince, diğerine karşı kesilmiş olmaz.

${ }^{64}$ Bkz. ŞAHIN CANER, s. 132; KAYIHAN, s. 1598 vd; ARĞILLI, s. 81. 
ödeyeceği tazminat TBK 51 / I ve 52 / II gereğince, 100 TL'den daha düşük bir tutarda olabilecektir. Fakat bu olayda malik bu malı için 100 TL bedelli bir mal sigortası akdetmişse, bu hasar karşısında sigorta şirketi 100 TL'lik hasarın tamamını gidermekle yükümlüdür. Eğer zarar veren ile mal sigortacısı müteselsil borçlu sayılırsa, zarar veren aleyhine açılan dava sonucunda zarar görene $100 \mathrm{TL}$ tazminat ödemek zorunda kalabilecektir. Zarar veren, bu zararın tamamını ödedikten TBK 62 / II gereğince halef olarak sigorta şirketine rücu edebilir. Zararın ortaya çıkmasında sigorta şirketinin hiçbir kusuru olmadığından, bu rücu talebinin dayanağı da olmayacaktır. Fakat bu olayda sigortacı olmasaydı, zararın çok küçük bir kısmını karşılamak zorunda kalacaktı. Görüldügü gibi mal sigortasında, sigortacı ile zarar verenin müteselsil borçlu sayılması, hem teorik sebeplerle, hem de adil olmayan sonuçların ortaya çıkması nedeniyle kabul edilmemelidir.

Mal sigortacisı ile haksız fiil failleri arasında müteselsil borçluluk olmadığını kabul ettiğimizden, sigorta şirketi zararı karşıladığında, TBK 62 / II hükmüne göre değil (çünkü zarar sigortacısı müteselsil borçlu değildir), TTK 1472 / I gereğince sigortalının yerine geçer. Sigortalının, gerçekleşen zarardan dolayı sorumlulara karşı var olan dava hakları sigorta şirketine geçer. Bunun sonucu olarak da sigortalının sorumlulara karşı olan talep hakları, hukuki dayanakları ${ }^{65}$ ve bağlı oldukları zamanaşımı süreleri değişmeksizin sigorta şirketine geçmiş olur ${ }^{66}$.

Bu durumda (zarar gören) sigortalıya karşı müteselsilen sorumlu olanlar, sigorta şirketine karş1 da müteselsilen sorumlu olur ${ }^{67}$. Sigorta şirketinin bu alacağının zamanaşımı süresi, sigortalının sahip olduğu zamanaşımı süresi kadardır. Mal sigortasında sigorta şirketi müteselsil borçlu sayılmadığından, sigortalının sigorta şirketine dava açması, sigorta şirketinin kısmi ifada bulunması, müteselsil borçlular yönünden zamanaşımını kesmez.

Zarar sigortasının ikinci türü ise sorumluluk sigortalarıdır. Sorumluluk sigortasında rücu ve halefiyet sorununun çözümünde, öncelikle sorumluluk sigortacısının borcunun niteliği tespit edilmelidir. Sorumluluk sigortasında

\footnotetext{
${ }^{65}$ Sigortalı ile zarar veren arasındaki hukuki ilişkide, zarar verenin sorumluluğu geçerli biçimde ortadan kaldırılmışsa, sigortacı yaptığı ifayla halefiyet ve zarar verene başvuru imkânına sahip olmayacaktır. Bkz. BOZER, Rücu, s. 478.

66 TEKINAY / AKMAN / BURCUOĞLU / ALTOP, s. 722; NOMER, (2011), s. 252; BOZER, Zamanaşımı, s. 475; KAYIHAN, s. 1604; ARĞILLI, s. 87. Bkz. YİBK 17.01.1972, 1970/2, 1972/2, RG. 20.03.1972, S. 14134.

67 DALCI ÖZDOĞAN, s. 118; ŞAHIN CANER, s. 132.
} 
sigorta şirketi, aslında sigortalının bir tazminat yükümlülüğü doğduğunda, sigortalıya karşı, onu bu borçtan kurtarmayı borçlanır ${ }^{68}$. Bu borcun ifası, ya sigortalının zarar görene ödemesi gereken tazminat tutarının sigorta şirketi tarafindan sigortalıya ödenmesiyle, ya da bu ödemenin doğrudan zarar görene yapılmasıyla gerçekleştirilebilir. Bu sebeple sigortacının ediminin, sigortalıyı, üçüncü kişinin tazminat talebi karşısında bu borçtan kurtarmaktan ibaret olduğu görülmektedir.

Fakat TürkTicaretKanununun 1473. maddesinde, sorumluluksigortasında sigortalının üçüncü bir kişiye karşı, sigorta sözleşmesinde öngörülen türden bir sorumluluğunun doğması halinde, sigortacının doğrudan zarar görene, sigorta sözleşmesinde öngörülen miktara kadar tazminat ödeyeceği açıkça düzenlenmiştir. Böylece sigorta şirketinin edim yükümlülüğünün, sigortalının mal varlığının pasifinin artmasında doğacağı kabul edilmiştir.

Aynı şekilde bunun tamamlayıcısı olan TTK 1478 hükmünde de, zarar görenin doğrudan sigortacıya başvurabileceği bir genel hüküm niteliğinde olmak üzere açıkça düzenlenmiştir ${ }^{69}$. Böylece zarar gören, sigorta şirketi karşısında sadece edimi kabul eden biçimindeki pasif konumdan çıkarılıp, aktif olarak edimin kendisine ifasını talebe de yetkili hale getirilmiştir ${ }^{70}$.

$\mathrm{Bu}$ hükümlerin hukuki niteliğiyle ilgili tartışmalar konumuzun dışındadır ${ }^{71}$. Meselenin konumuzu ilgilendiren kısmı, zarar görene, fail dışında doğrudan sorumluluk sigortacısına da başvuru hakkının tanınmış olması nedeniyle sorumluluk sigortacısının diğer sorumlularla birlikte müteselsil borçlu sayılmasının mümkün olup olmadığıdır.

$\mathrm{Bu}$ konuda bir kanaat açıklarken, sorumluluk sigortasında ilgililerin (sigortalı, sigorta şirketi ve zarar görenin) hukuki durumları incelenmelidir. TTK 1473 ve 1478 hükümleri birlikte incelendiğinde, sorumluluk sigortasının tam üçüncü kişi yararına sözleşme niteliği taşıdığı kabul edilebilir ${ }^{72}$. Tam

\footnotetext{
68 Bkz. TEKİNAY / AKMAN / BURCUOĞLU / ALTOP, s. 222; YEŞILLOVA ARAS, s. 28.

69 TTK 1478: "Zarar gören, uğradĭg zararın sigorta bedeline kadar olan kısmının tazminini, sigorta sözleşmesi için geçerli zamanaşımı süresi içinde kalmak şartıyla, doğrudan sigortacldan isteyebilir."

70 YEŞILILOVA ARAS, s. 33.

71 Bu konuda bkz. YEŞİLOVA ARAS, s. 64 vd.

72 Bu yönde: OĞUZMAN / ÖZ, (2017), no.1272; KILIÇOĞLU YILMAZ, s. 1763; TEKİNAY / AKMAN / BURCUOĞLU / ALTOP, s. 223; GAUTSCHI, s. 56; KOLLER, s. 1174.

Bu konudaki tartışmalar ve literatür için bkz. YEŞILILOVA ARAS, s. 78.
} 
üçüncü kişi yararına sözleşmede vaat ettiren olarak ifade edilen sorumluluk sigortalıs1, sigorta tazminatının lehtara, yani zarar görene ödenmesini talep yönünde bir alacak hakkına sahiptir ${ }^{73}$. Lehtar, yani zarar gören de, doğrudan vaat edene, yani sorumluluk sigortacısına başvurup, alacağın kendisine ifasını talep yetkisine sahiptir. Genel olarak kabul edildiği üzere, tam üçüncü kişi yararına sözleşmede, hem vaat ettiren, hem de lehtar bir alacak hakk1 sahibidir ${ }^{74}$. Vaat ettirenin alacağ1, tazminatın zarar görene ödenmesi yönündeyken; lehtarın alacağı ise, (zarar veren sigortalının sorumlu olduğu ve sigorta bedeli içinde kaldığı ölçüde) tazminatın kendisine ödenmesini talep yönündedir.

Kanundan doğan bir tam üçüncü kişi yararına sözleşme olarak kabul ettiğimiz sorumluluk sigortasında lehtar, yani zarar gören, doğrudan sigorta şirketine başvurup (sigortalının sorumlu olduğu ve sigorta bedeli içinde kaldığ ölçüde) zararını karşılayacak tazminatın ödenmesini isteyebileceğinden ${ }^{75}$, zarar gören ile sigorta şirketinin müteselsil borçlu olduğu sonucuna ulaşı1mıştır ${ }^{76}$.

Yargıtay kararlarında ve doktrinde, TTK 1478 benzeri bir hüküm içeren KTK 97 gereğince sorumluluk sigortacısının diğer sorumlularla birlikte müteselsil borçlu olduğu kabul edilmektedir ${ }^{77}$.

73 Tam üçüncü kişi yararına sözleşmede vaat ettiren, vaat eden ve lehtarın karşılıklı hukuki durumları hakkında bkz. TEKINAY / AKMAN / BURCUOĞLU / ALTOP, s. 220 vd; BUCHER, s. 480 vd; KOLLER, s. 1188; ÖZ, m. 129, no. 34; ÇİLENTİ KONURALP, s. 156 ve özellikle s. 173.

74 OĞUZMAN / ÖZ, (2017), no. 1306; ÖZ, m. 129, no. 34; KILIÇOĞLU YILMAZ, s. 1767; ÇİLENTİ KONURALP, s. 173, dn.96'de anılan yazarlar.

75 Genel hüküm niteliği taşıyan TTK 1478 yanında, sorumluluk sigortalarına ilişkin çeşitli kanunlarda düzenlenen (doğrudan sigortacıya başvuru hakkını veren) hükümler de mevcuttur. TBK 130 / I: "Başkasını çalıştıran kişi, çalıştırdığı kişiye karşı hukuki sorumluluğunu güvence altına almak üzere sigorta yaptırmışsa, sigortadan doğan haklar doğrudan doğruya çalı̧̧ana ait olur."

KTK 97: "Zarar görenin, zorunlu mali sorumluluk sigortasında öngörülen sinırlar içinde dava yoluna gitmeden önce ilgili sigorta kuruluşuna yazılı başvuruda bulunması gerekir. Sigorta kuruluşunun başvuru tarihinden itibaren en geç 15 gün içinde başvuruyu yazılı olarak cevaplamaması veya verilen cevabın talebi karşılamadiğına ilişkin uyuşmazlık olması hâlinde, zarar gören dava açabilir veya 5684 sayılı Kanun çerçevesinde tahkime başvurabilir."

Karayolları Taşıma Kanunu 21: "Hak sahipleri, sorumluluk sigortasında öngörülen sinırlar içinde doğrudan doğruya sigortacıya karşı talepte bulunabilirler."

76 Bu yönde: KOLLER, s. 1209; YEŞİLOVA ARAS, s. 87.

Açık olmamakla birlikte aksi görüşte: KAPANCI, (2019), m. 61-62, no. 35.

77 Bu yöndeki kararlar için bkz. YEŞİLOVA ARAS, s. 85, dn. 228. Ayrıca bkz. ŞAHİN CA- 
$\mathrm{Bu}$ sebeple sorumluluk sigortasında sigortacıya karşı zamanaşımı kesilince, faile karşı da kesilmiş sayılır ${ }^{78}$.

Sorumluluk sigortasında sigortac1, zarar verenle birlikte müteselsil borçlu sayıldığına göre, sigortacının zarar gören alacaklıya ifada bulunmasıyla ortaya çıkan hukuki durumun açıklanması gerekir. Sigortacı müteselsil borçluysa, yaptığ1 ifayla alacaklının haklarına halef olması gerekir (TBK 62 / II, TBK 168 / I). Fakat sorumluluk sigortac1 ifada bulunduğunda, onun halefiyetinin alacaklıya değil, TTK 1481 / I gereğince sigortalıya olduğu açık hükümle belirtilmiştir: "Sigortalının gerçekleşen zarardan dolayı sorumlulara karşı dava hakkı varsa bu hak, tazmin ettiği bedel tutarında sigortaclya ait olur."

Mesela bir inşaat işini yürüten (A) şirketinin, hafriyat işini yapan (I)şçi'si hafif kusurlu davranışı sonucunda bu işin görüldüğü sırada yoldan geçen bir kişiye zarar vermiş ve (A) ile (I) arasındaki iş sözleşmesinde, işçinin hafif kusurundan işverene karşı sorumluluğu tamamen kaldırılmış bulunsun. Bu olayda (A) şirketinin, bu olayı da kapsayan bir sorumluluk sigortası varsa, zarar gören, TTK 1478 hükmü gereğince doğrudan sigorta şirketinden talepte bulunabilir. Sigorta şirketi ödeme yaptığında, TBK 62'ye göre alacaklı zarar görene değil, TTK 1481 / I gereğince sigortalı inşaat şirketine halef olur ${ }^{79}$. $\mathrm{Bu}$ durumda halefiyete dayalı rücu hakkını da, aynı hükme göre gerçekleşen zarardan dolayı sigortalıya karşı sorumlu olan (I)'ye karşı kullanabilir. Fakat iş sözleşmesinde hafif kusurdan sorumluluk kaldırıldığından, bu olayda rücu talebi reddedilecektir.

Fakat eğer sigorta şirketinin halefiyeti zarar gören alacaklıya olsayd1, onun halefiyete dayalı başvurusunda (I), hafif kusurlu olarak tazminatın bir

NER, s. 43, dn. 116.

Sorumluluk sigortacısının müteselsil borçlu olduğunu kabul edenler: KILIÇOĞLU, (2014), s. 465; GÖKCAN, s. 1377; ŞAHİN CANER, s. 129 vd; NOMER, (2015), s. 204; BAĞRIAÇIK, s. 269; YAĞCIOĞLU, s. 236.

DALCI ÖZDOĞAN'ın (s. 118) açıklamalarından yazarın sorumluluk sigortacısını müteselsil borçlular arasında görmediği anlaşılmaktadır.

78 Bu sonuç, KTK zorunlu mali sorumluluk sigortası için açık hükümle (m.109 / III) kabul edilmiştir: "Zamanaşımı, tazminat yükümlüsüne karşı kesilirse, sigortacıya karşı da kesilmiş olur. Sigortacı bakımından kesilen zamanaşımı, tazminat yükümlüsü bakımından da kesilmiş sayllır."

Aynı hüküm, Karayolları Taşıma Kanununa göre zorunlu tutulan sorumluluk sigortası için de açık hükümle (m.23) kabul edilmiştir: "Sorumlu kişi hakkındaki zamanaşımını kesen sebepler, sigorta şirketi hakkında da uygulanır. Sigorta şirketi hakkında zamanaşımını kesen sebepler sorumlu kişi hakkında da uygulanır."

79 Bkz. ve karş. KAPANCI, (2019), m. 61-62, no. 35, dn. 159; ARĞILLI, s. 81. 
kısmını üstlenmek zorunda kalacaktı. Bu sebeple, doktrinde ileri sürülen, sorumluluk sigortacısının TBK 62 / II hükmüne göre halef olacağı yönündeki görüşlere ${ }^{80}$ katılma olanağı yoktur. Sorumluluk sigortacının yaptığı ifayla özel hüküm niteliği taşıyan TTK 1481 / I gereğince, TBK 62 / II'nin aksine alacaklıya değil, sigortalıya halef olduğu sonucuna ulaşılmıştır.

Sigorta şirketi sigortalının yerine geçtiğine göre, sigortalıya karşı sorumlu olanlara, onun hukuki durumu neyse o şekilde başvurabilecektir. Sigortalı, tazminatın tamamını kendisi ödeseydi, diğer müteselsil borçlulara hangi hukuki sebeple ve hangi miktarda rücu edebilecekse, onun halefi olan sigortacı da aynı hukuki zeminde talepte bulunacaktır ${ }^{81}$. Bu yönüyle mesela sorumluluk sigortalısının yanında 2 sorumlu daha varsa, halefiyete dayanan sigortacı (müteselsil borçlu) sigortalının yerine geçecek ve sigortalı diğer iki müteselsil borçluya nasıl rücu edebilecekse o şekilde rücu edecektir. $\mathrm{Bu}$ sebeple bu aşamada rücu müteselsil değil, paylı olacaktır ${ }^{82}$.

Sorumluluk sigortacısının rücu hakkıyla ilgili son olarak belirtilmesi gereken konu ise, sorumluluk sigortacısının, sigortalının sorumluluğunun doğduğu hallerde ortaya çıkan zararı, zarar görene (sigorta limiti ölçüsünde) ödemesinden sonra, bazı durumlarda sigortalıya rücu edip, ödediği tazminatın iadesini isteyebileceği kabul edilen durumlardır. Halefiyetle ilişkisi olmayan bu iade borcu (rücu alacağı), sigorta sözleşmesinden kaynaklanır ${ }^{83}$.

Mesela Kara Yolları Trafik Kanunu Mali Sorumluluk Sigortası genel şartlarının B.4. maddesinde belirtilen durumlarda sigortacının ödediği tazminat için sigortalıya rücu edebileceği düzenlenmiştir ${ }^{84}$. TTK 1420 / I gereğince

80 NOMER, (2011), s. 252.

81 Bu yönde: YİBK 17.01.1972, 1970/2, 1972/2, RG.20.03.1972, S. 14134.

82 ŞAHIN CANER, s. 133.

DALCI ÖZDOĞAN, s. 119'ise, bu rücuun müteselsil olacağını belirtmiştir. Fakat yazarın bu kanaati sorumluluk sigortası için değil, mal sigortası için yaptığı da anlaşılmaktadır.

83 KAYIHAN, s. 1608

84 ZMSS Genel Şartları madde B.4. fikra II: “Ödemede bulunan sigortacı, sigorta sözleşmesine ve bu sözleşmeye ilişkin kanun hükümlerine göre, tazminatın kaldırılmasını veya azaltılmasını sağlayabileceği oranda kazaya sebebiyet veren sigortalıya rücu edebilir.

Sigortallya başlıca şu nedenlerle rücu edilir:

a) Tazminatı gerektiren olay, sigortalının veya eylemlerinden sorumlu olduğu kişilerin kasti bir hareketi veya ağır kusuru sonucunda meydana gelmiş ise,

b) Tazminatı gerektiren olay, aracin ilgili mevzuat hükümlerine göre gereken ehliyetnameye sahip olmayan veya geçerliliğini yitirmiş sürücü sertifikasına sahip ya da ehliyetine geçicil 
"sigorta sözleşmesinden doğan bütün istemler, alacă̆ın muaccel olduğu tarihten başlayarak iki yll(lık)..." zamanaşımı süresine tabidir ${ }^{85}$. Bu hükme göre sigortac1, mesela işletenin uyuşturucu madde etkisi altında bir kazaya neden olması halinde de zarar görenin zararını karşılar ve fakat daha sonra kendi iç ilişkisi gereğince (açılklanan hükme göre) işletene rücu edebilir ${ }^{86}$.

Aynı şekilde sorumluluk sigortasının bulunduğu bir durumda zarar gören, uğradığı zararı sigortalıdan tahsil etmişse, zarar veren, aralarındaki sigorta sözleşmesi hükümlerine göre sigorta şirketine başvurup, kendisinin zarar görene ödemek zorunda kaldığı ve sigortacının karşılamakla yükümlü olduğu tutarın kendisine ifasını talep edebilir ${ }^{87}$. Bu talep sigorta sözleşmesinden doğan bir rücu talebi niteliği taşır. Kabul ettiğimiz görüş gereğince, sigorta sözleşmesi tam üçüncü kişi yararına sözleşme olduğuna ve tam üçüncü kişi yararına sözleşmede vaat ettiren, yani sigortalı, kendisinin sorumlu olduğu fiilden doğan üçüncü kişinin zararının, sigorta bedeli içinde kaldığ 1 ölçüde karşılanmasını sigorta şirketinden talebe yetkilidir. Fakat sigorta şirketi bu borca aykırı davranmış ve tazminatı zarar veren ödemişse, sigorta sözleşmesi hükümlerine göre şirkete rücu edip, bu tutarın kendisine ödenmesini talep

sürekli el konulmuş kimseler tarafindan sevk edilmesi veya trafik kurallarının ağır kusur ile ihlali ${ }^{(2)(11)(16)}$ sonucunda meydana gelmiş ise ${ }^{(3)(5)(7)(13)(14),}$

c) Aracın, uyuşturucu madde veya ilgili mevzuatta belirlenen seviyenin üzerinde alkollü içki almış kişilerce veya aynı mevzuatta alkollü içki alamayacağı belirtilen kişilerce alkollü içki alınmak suretiyle kullanılması sirasinda meydana gelen zararlar,

ç) Tazminatı gerektiren olay, yolcu taşımaya ruhsatl olmayan araçlarda yolcu taşınması veya yetkili makamlarca tespit edilmiş olan istiap haddinden fazla yolcu veya yük taşınması veya patlayıcı, parlayıcı ve tehlikeli maddeleri taşıma ruhsatı bulunmayan araçlarda, bu maddelerin parlama, tutuşma ve infilakl yüzünden meydana gelmiş ise,

d) Sigortalının rizikonun gerçekleşmesi halinde bu genel şartların B.1. maddesinde belirtilen yükümlülükleri yerine getirmemesinden dolayı zarar ve ziyan miktarında bir artış olur$s a$,

e) Tazminatı gerektiren olayın aracın çalınması veya gasp edilmesi sonucunda olması halinde, çalınma veya gasp edilme olayında sigortalının kendisinin veya eylemlerinden sorumlu olduğu kişilerin kusurlu olduğu tespit edilirse,

f) Bedeni hasara neden olan trafik kazalarında sigortalının veya eylemlerinden sorumlu olduğu kişilerin, tedavi veya yardım amaçlı sağlık kuruluşuna gitme, can güvenliği nedeniyle uzaklaşma gibi zorunlu haller hariç olmak üzere, olay yerini terk etmesi veya kaza tutanağl, alkol raporu vb. kazanın oluş koşullarına ilişkin gereken belgelerin düzenlenmesi yükümlülüğ̈ne aykırı davranması halinde,"

Bu hüküm hakkında bkz. KAYIHAN, s. 1610 vd.

85 GÖKCAN, s. 490; MEMİş, s. 1933.

86 BAĞRIAÇIK, s. 266.

87 YEŞiLOVA ARAS, s. 31, dn.20. 
edebilir. Bu talebin bağlı olduğu zamanaşımı süresi, yine TTK 1420 / I gereğince iki yıldır.

\section{Müteselsil Borçlular Arasında Bir Sözleşme İlişsisinin Bulunmaması Halinde Rücu Talebi}

Müteselsil borçlular arasında bir sözleşme ilişkisinin olmadığı hallerde rücu talebinin bağlı olduğu zamanaşımını ortaya koyarken, TBK 73 hükmüyle haksız fiilden doğan müteselsil borçluluktaki rücu zamanaşımına ilişkin getirilmiş bulunan özel hüküm dikkate alınarak, yine iki durumu birbirinden ayırt etmek gerekir: 1 . Müteselsil borçluluğun haksız fiilden kaynaklandığ hallerde rücu, 2. Müteselsil borçluluğun haksız fiil dışında bir sebeple ortaya çıktığı hallerde rücu.

1. Müteselsil borçlular arasında bir sözleşme ilişkisinin olmadığı ve müteselsil borçluluğun haksız fiilden kaynaklandığı hallerde rücu talebi (TBK 73)

\section{a. Genel Olarak}

Bilindiği gibi TBK 61 hükmünde düzenlenen müteselsil sorumluluk, aynı zarara (aynı veya farklı hukuki sebeplere dayalı olarak) yol açan birden çok kişinin bu zararı tazmin borcunun müteselsil borçlusu olmasını ifade eder. Bu yönüyle müteselsil sorumluluk olarak ifade edilen kurum, aslında bir müteselsil borçluluktur ${ }^{88}$. Zaten Kanunda, müteselsil borçluluk hükümlerine yollama yapılmıştır. Bu sebeple, TBK 61 hükmünde geçen "birden çok kişi ... taktirde, haklarında müteselsil sorumluluğa ilişkin hükümler uygulanır." ifadesinin "birden çok kişi ... taktirde, haklarında müteselsil borçluluğa ilişkin hükümler uygulanır." biçiminde algılanması gerekir ${ }^{89}$.

Yapılan bu yollama gereğince, haksız fiil nedeniyle birden çok kişinin müteselsilen borçlu olması halinde, sorumluluk hukuku kısmında özel bir hüküm yoksa (mesela zararın iç ilişkide paylaşılmasına ilişkin TBK 62 / I'de olduğu gibi), müteselsil borçluluğa ilişkin TBK 162 - 168 hükümleri uygulanır.

88 Müteselsil sorumluluğun, müteselsil borçluluğun bir türü olduğu, kanundan doğan bir müteselsil borçluluk olduğu görüşünde: OĞUZMAN / ÖZ, (2017), no. 846; KAPANCI, (2019), m. 61-62, no. 3; YAĞCIOĞLU, s. 7, 8.

89 Doktrinde de örtülü olarak bu hususun ifade edildiği söylenebilir. NOMER, (2012), s. 55; KAPANCI, (2014), s. 35; BAYSAL, s. 615; KIRCA, s. 24. 
Müteselsil borçluluğa ilişkin TBK 162 - 168 hükümlerinde, rücu taleplerindeki zamanaşımına ilişkin bir hüküm bulunmamaktadır. Aslında bulunması doğru da değildir. Zira çalışmamızda savunulduğu üzere müteselsil borçluların iç ilişkideki birbirlerine yönelik rücu talepleri, onlar arasındaki hukuki ilişkiye göre belirlenir. Bu sebeple onların arasındaki hukuki ilişki görmezden gelinip bir genel sürenin kabulü doğru olmaz.

Fakat haksız fiilden doğan müteselsil borçlulukta rücu talepleri konusunda TBK 73 hükmüyle bir özel zamanaşımı süresinin getirildiği görülmektedir ${ }^{90}$. Haksız fiilden doğan müteselsil borçluluğa dayalı rücu taleplerinde zamanaşımını düzenleyen TBK 73 hükmü 6098 sayılı TBK ile hukukumuza girmiş bir hükümdür ${ }^{91}$.

Bu hüküm, haksız fiil temelli müteselsil borçlular arası özel rücu talebinin bağlı olduğu zamanaşımı süresine ilişkindir. Bu hükmün, halefiyete dayalı genel rücu ilişkilerine yönelik bir etkisi yoktur ${ }^{92}$. Ayrıca müteselsil borçluların borçluluğunun temeli bir haksız fiil değilse, müteselsil borçlular arası rücu ilişkilerinde TBK 73 hükmü yine uygulanamaz ${ }^{93}$.

Yukarıda da açıklandığı gibi, haksız fiile dayalı müteselsil borçlulukta da, borçlulardan birinin yaptığı payından fazla tutardaki ifayla, diğerlerine rücu hakkı doğar. Bu rücu hakkı, temelini, müteselsil borçlular arasındaki

90 TBK 73 hükmü, geniş anlamda haksız fiil sorumluluğu bulunan birden çok kişinin müteselsil sorumluluğu halinde uygulanabilir. Bu hüküm, haksız fiil sorumluluğu dışındaki müteselsil borçluluk hallerinde ortaya çıkan rücu ilişkilerinde uygulama alanı bulmayacaktır. NOMER, (2011), s. 249; ÇELİK, m.73, no.3. Aksi görüşte: DALCI ÖZDOĞAN, s. 223; YAĞCIOĞLU, s. 403.

$91 \mathrm{Bu}$ hüküm, yasalaşma şansı bulamayan bir İsviçre tasarısından alınmıștır. Widmer/Wessner Tasarısı olarak anılan bu tasarının 55c maddesi şöyleydi: "(1) Rücu istemi, tazminatın tamamının ödendiği ve birlikte sorumlu kișinin ögrenildiği tarihten bașlayarak 3 yılın ve her halde zarar verici fiilin meydana geldiği veya sona erdiği tarihten başlayarak 20 yılın geçmesiyle zamanaşımına uğrar. (2) Tazminatın ödenmesi kendisinden istenen kişi, durumu birlikte sorumlu kişilere bildirmek zorundadır. Aksi halde zamanaşımı, bu bildirimin dürüstlük kurallarına göre yapılabileceği tarihte işlemeye başlar.” Bu hüküm için bkz. BAYSAL, s. 693.

92 Doktrinde de TBK 73 hükmünün halefiyete dayalı rücu hakk1 için değil, özel rücu hakk1 içi getirilmiş bir hüküm olduğu haklı olarak ileri sürülmüştür. Nomer'e göre TBK 73 hükmü, halefiyete dayalı rücu hakkı için uygulanmaz. Aksi takdirde teminat verenlerin durumu, kendi iradeleri dışında ağırlaşmış olurdu. NOMER, (2011), s. 251.

Doktrinde Kapancı da bu zamanaşımı süresinin helefiyete dayalı alacak için değil, rücua dayalı özel alacak için geçerli olduğunu kabul etmektedir. KAPANCI, (2014), s. 554. Bu yönde: KILIÇOĞLU, (2014), s. 506; YAĞCIOĞLU, s. 249 vd.

93 NOMER, (2011), s. 249. 
hukuki ilişkiden alır. Müteselsil borçlular arasında bir sözleşme varsa, rücu bu sözleşme hükümlerine göre yapılır. Fakat borçlular arasında bir sözleşme ilişkisi yoksa, bu rücu talebi somut olayın özelliklerine göre vekaletsiz iş görme veya sebepsiz zenginleşmeye dayandırılabilir. Fakat diş ilişkideki sorumluluk haksız fiil ise ve müteselsil sorumlular arasında bir sözleşme ilişkisi yoksa veya varlığı iddia edilen bu sözleşmesel ilişki kanıtlanamamışsa, rücu edilecek tutar TBK 62 / I hükmüne göre belirleneceği gibi, bu talebin bağlı olduğu zamanaşımı süresi de TBK 73 hükmüne göre belirlenecektir.

Bu sebeple, TBK 73 hükmünün, rücu zamanaşımı yönünden talebin vekâletsiz iş görme veya sebepsiz zenginleşme olarak nitelenebileceği durumların önünü tıkadığ 1 ve bir özel hüküm olarak rücu ilişkisini düzenlediği kanaatine ulaşılmıştır.

Doktrinde, bu hükmün önemli bir boşluğu doldurduğu ileri sürülmüştür ${ }^{94}$. Fakat bu hükümle sadece kanun koyucu haksız fiile dayalı rücu talepleri yönünden, müteselsil borçlular arasında bir sözleşme ilişkisinin bulunmadığ 1 hallerde rücu talebinin vekâletsiz iş görme mi, yoksa sebepsiz zenginleşme mi niteliği taşıdığı yönündeki tartışmay1 ${ }^{95}$ ve buna bağlı olarak uygulanacak olan zamanaşımı süresi farklılığını görmezden gelmek suretiyle meseleyi tek bir hükümle çözme iradesini ortaya koymuştur ${ }^{96}$.

Fakat yine belirtelim ki, TBK 73 hükmü, rücu talebinin, müteselsil borçlular arasındaki sözleşme ilişkisine dayandığı hallerde uygulanamaz ${ }^{97}$. Bir sözleşmenin taraflarının, kendilerinin üçüncü kişiye karşı müteselsilen sorumlu olması halinde, zararın iç ilişkide nasıl paylaştırılacağına yönelik akdettikleri sözleşmelerinin görmezden gelinmesi doğru değildir.

TBK 73 hükmüne göre rücu talebi, iki yıllık k1sa ve 10 yıllık uzun zamanaşımı sürelerine bağlıdır. Fakat kanunda, bu sürelerin işlemeye başlaması, genel kural olan muacceliyete bağlanmış değildir. Bu sebeple zamanaşımı sürelerinin işlemeye başlamasının ayrıca incelenmesi gerekir.

94 NOMER, (2011), s. 249; KAPANCI, (2014), s. 556; KAPANCI, (2019), m. 61-62, no. 37; BAYSAL, s. 639. KIRCA, s. 49; DALCI ÖZDOĞAN, s. 218; AŞIK, s. 81.

95 Bkz. DALCI ÖZDOĞAN, s. 213 vd.

96 ÇELIK, m. 73, no. 1.

97 Bu yönde: KAPANCI, (2019), m. 61-62, no. 36, dn. 165; OĞUZMAN / ÖZ, (2017), no. 862. 


\section{b. Sürelerin İşlemeye Başlaması}

TBK 73 hükmüne göre rücu alacağının bağlı olduğu iki yıllık süre, tazminatın tamamının ödendiği ve birlikte sorumlu olunan diğer kişinin öğrenildiği andan itibaren işlemeye başlarken, rücu alacağının bağlı olduğu 10 yıllık uzun süre ise, tazminatın tamamının ödendiği tarihten işlemeye başlar. Bu hüküm nedeniyle, öncelikle 10 yıllık sürenin işlemeye başlaması, ardından ise bir ek koşulun daha arandığ 2 yıllık sürenin işlemeye başlaması incelenmelidir.

\section{aa.10 yıllık uzun sürenin işlemeye başlaması}

Rücu hakkına sahip olan müteselsil borçlunun bu hakkını kullanmasındaki üst zamanaşımı süresi 10 yıldır. Bu süre, rücu hakkına sahip olan müteselsil borçlunun, tazminatın tamamını ödediği tarihte işlemeye başlar. Bu ödemenin bir dava sonucunda verilen mahkeme kararına dayanması gerekli değildir ${ }^{98}$.

Tazminatın tamamının ödenmesi, alacaklının (zarar görenin) ifa veya başka bir biçimde tamamen tatmin edilmesini ifade eder. Bu sebeple 10 yıllık sürenin işlemeye başlaması, mesela müteselsil borçlulardan birinin, zarar görenden olan karşı edim alacağını takas etmesi yoluyla tazminatın tamamının karşılanmış sayıldığı hallerde de işlemeye başlar.

10 yıllık süre, tazminatın tamamının ödenmesiyle başlayacağına göre, tazminatın kısmen ifa edilmesi halinde, 10 y1llık süre işlemeye başlamayacaktır ${ }^{99}$. Mesela tazminat tutarı $100 \mathrm{TL}$ ise ve tazminatın ödendiği tarihte 20 TL'de temerrüt faizi doğmuş ve alacaklı 110 TL ödeme yapmışsa, tazminatın 10 TL'lik kısmı halen ifa edilmemiş olacağından, 10 yıllık zamanaşımı süresi işlemeye başlamamış olacaktır.

Doktrinde bu hükümde, zamanaşımının alacağın muaccel olmasıyla başlayacağına ilişkin genel ilkeyle paralellik olduğu ileri sürülmüştür ${ }^{100}$. Fakat kanaatimce bu görüsse katılmak mümkün değildir. Zira genel ilkeyle paralellik olsaydı, (iç sorumluluk payını aşan tutardaki) kısmi ifa halinde bu kısım için zamanaşımı derhal başlayabilirdi ${ }^{101}$. Çünkü verdiğimiz örnekte rücu hakkı,

\footnotetext{
98 KAPANCI, (2019), m. 61-62, no. 36.

99 EREN, s. 946; KILIÇOĞLU, (2014), s. 507; NOMER, (2011), s. 254; DALCI ÖZDOĞAN, s. 218; KIRCA, s. 50; ÇELIK, m. 73, no. 10; TUTUMLU, s. 314.

${ }^{100}$ KAPANCI, (2014), s. 555; KAPANCI, (2019), m. 61-62, no. 36; YAĞCIOĞLU, s. 391; KURT, s. 152.

${ }^{101}$ Bu yönde: DALCI ÖZDOĞAN, s. 220.
} 
payından fazla ifada bulunmakla zaten muaccel hale gelmiştir. Fakat borcun tamamı ödenmediği için zamanaşımı işlemeye başlamayacaktır.

Zamanaşımı süresinin başlaması için önemli olan, tazminatın tamamının ödenmiş olmasıdır. Bu ödemenin kim tarafindan yapıldığı önem taşımaz. Bu sebeple mesela müteselsil sorumlulardan birinin 120 TL'lik tazminatın 100 TL'sini ödemesinden 5 yıl sonra diğer sorumlu da tazminatın kalan kısmını ödemişse, rücu zamanaşımının başlaması için aranan ilk unsur olan tazminatın tamamının ödenmesi koşulu, 5. yılda gerçekleşmiş sayılacaktır ${ }^{102}$.

Zamanaşımının, tazminatın tamamının ödenmesine bağlanması, doktrinde haklı eleştiri konusu olmuştur ${ }^{103}$. Müteselsil borçluların kimliklerinin de bilindiği ve payından fazla bir miktarda ödemede bulunulduğu hallerde, henüz borcun tamamının ödenmediği için rücu talebinin zamanaşımının neden işlemeye başlamadığını anlamak güçtür.

10 yıllık sürenin tazminatın tamamının ödenmesine bağlanması da, bu üst sürenin çok uzun yıllar boyunca işlemeye başlamaması gibi bir sonuç doğurabiliir ${ }^{104}$. Hemen belirtelim ki, Widmer / Wessner Tasarısında olduğu gibi, hükmün bizdeki tasarı aşamasındaki şeklinde de, üst süre haksız fiil tarihinden başlatılmaktaydı. Fakat 10 y1llık üst sürenin fiil tarihinden başlatılması halinde de, ifa tarihinde bu sürenin geçmiş olması durumunda, rücu alacağının doğmasından önce zamanaşımına uğraması sonucu ortaya çıkabilecekti ${ }^{105}$. Bu yönüyle 10 yıllık sürenin paydan fazla tutarda (tamamına değil) ödemeye bağlanması en uygun yoldur ${ }^{106}$.

\section{ab.2 yıllık kısa sürenin işlemeye başlaması}

2 yıllık sürenin işlemeye başlaması için iki ayrı koşulun birlikte gerçekleşmesi gerekir. Bunların ilki, 10 yıllık sürenin işlemeye başlamasıyla aynıdır: Tazminatın tamamının ödenmesi. Bu konu için bir önceki başlıkta açıklananlar aynen geçerlidir. Fakat şunu belirtmek gerekir ki, en azından iki yıllık sürenin işlemeye başlamasında tazminatın tamamının ifasının değil,

\footnotetext{
${ }^{102}$ KILIÇOĞLU, (2014), s. 507; ÇELİK, m. 73, no. 20.

${ }^{103}$ GÜRPINAR, s. 283; KAPANCI, (2014), s. 558; YAĞCIOĞLU, s. 397; NOMER, (2011), s. 254.

${ }^{104}$ GÜRPINAR, s. 283; KAPANCI, (2014), s. 559; BAYSAL, s. 640; NOMER, (2011), s. 255.

${ }^{105}$ Karş. KIRCA, s. 50; KURT, s. 153.

${ }^{106}$ DALCI ÖZDOĞAN, s. 220. Karş. YAĞCIOĞLU, s. 400; GÜRPINAR, s. 284.
} 
paydan fazla bir tutarda ifada bulunmanın aranması daha uygun olurdu ${ }^{107} . \mathrm{Bu}$ konuda başka bir açıklama yapmaksızın, ikinci koşul olan birlikte borçlu diğer kişilerin öğrenilmesi hususu incelenmelidir.

İki yıllık sürenin işlemeye başlamasının ikinci koşulu, rücu hakkına sahip müteselsil borçlunun, diğer müteselsil borçluyu öğrenmesidir.

Öğrenilecek olan, müteselsilen borçlu olan diğer bir kişinin varlığ1, kimliği ve iletişim bilgileridir ${ }^{108}$. Bunlardan birinin eksik olması halinde, 2 yıllık kısa zamanaşımı süresi işlemeye başlamaz.

Müteselsil borçlu sayısı en az 3 ise ve borcun tamamını ifa eden borçlu, diğer borçlulardan biri hakkında bilgi sahibiyse, onun bu kişiye yönelik rücu talebinin bağlı olduğu 2 yıllık zamanaşımı süresi diğer koşulun da gerçekleşmesi kaydıyla o tarihte işlemeye başlar. Üçüncü müteselsil borçlunun henüz bilinmemesi, ikinciye yönelik rücu talebi zamanaşımının işlemeye başlaması bakımından etkisizdir ${ }^{109}$.

Kanun öğrenmeyi esas almış olup, öğrenmenin gerekmesini dışlamıştır. $\mathrm{Bu}$ sebeple borçlunun gerekli özeni göstermesi halinde diğer borçluların kimliklerini öğrenebilecek durumda olması bile, bu şartın gerçekleşmesi için yeterli değildir ${ }^{110}$.

\section{ac.Bildirim külfetinin ihlali nedeniyle sürelerin daha önce işlemeye başlaması}

TBK 73 / II hükmüne göre,

"Tazminatın ödenmesi kendisinden istenen kişi, durumu birlikte sorumlu olduğu kişilere bildirmek zorundadır. Aksi halde zamanaşımı, bu bildirimin dürüstlük kurallarına göre yapılabileceği tarihte işlemeye başlar."

Bu hüküm, ilginç bir bakış açısıyla kaleme alınmıştır. Şöyle ki, müteselsil borçluya bir bildirim külfeti getirilmiş, buna uyulmazsa henüz doğmamış

\footnotetext{
${ }^{107} \mathrm{Bu}$ yönde: DALCI ÖZDOĞAN, s. 218.

${ }^{108}$ EREN, s. 946.

${ }^{109}$ KURT, s. 153; KAPANCI, (2014), s. 555; KAPANCI, (2019), m. 61-62, no. 36; YAĞCIOĞLU, s. 392; ÇELIK, m. 73, no. 21; DALCI ÖZDOĞAN, s. 220. Kılıçoğlu'nun konuyla ilgili açıklamalarında kullandığı çoğul ifadeden, bu kanaatte olmadığı anlaşılmaktadır. Bkz. KILIÇOĞLU, (2014), s. 507.

${ }^{110}$ KURT, s. 153; KAPANCI, (2014), s. 555; KAPANCI, (2019), m. 61-62, no. 36; DALCI ÖZDOĞAN, s. 220. Karş. ROTHENBERGER, s. 84.
} 
bulunan rücu alacağının zamanaşımı süresinin işlemeye başlaması gibi ${ }^{111}$ bir sonuç kabul edilmiştir.

Bu hükmün anlamı ve kapsamının özel olarak incelenmesi gerekir. Fakat öncelikle belirtelim ki, hukuki niteliği itibariyle bildirim, bir külfet niteliği taşı1 ${ }^{112}$.

Bildirim külfetinin doğumu: Kanunun açık hükmüne göre bildirim külfetinin doğumu tazminatın ödenmesinin müteselsil borçluların birinden istenmesiyle doğar. Bu bildirim külfetinin doğması, tazminatın sadece dava yoluyla talep edilmesi halinde mi doğar? Yoksa tazminatın dava dışı talep edilmesi halinde de, müteselsil borçlu bu durumu diğer müteselsil borçlulara bildirme külfeti altında mıdır?

$\mathrm{Bu}$ soruya cevap verirken, bildirim külfetinin hangi amaca hizmet ettiğini belirlemek gerekir. Kanaatimce bu bildirim külfetinin altında yatan sebep, bildirimin yapılması yoluyla davada daha lehe bir sonuç alınabilmesini sağlamaktır ${ }^{113}$. Bu hükmün alındığı İsviçre Borçlar Kanunu Ön Tasarısının açıklayıcı raporunda bunun amacı benzer biçimde şöyle açıklanmıştır: Bildirimin yapılmasıyla diğer sorumluların durumu öğrenip kendisinden talepte bulunulan kişiyi sorumluluktan kurtarmasını sağlamak ve ayrıca diğer sorumluların ellerindeki delillerin kaybolmasının önlenmek ${ }^{114}$.

Bu sebeple bu bildirim külfetinin doğması için davanın açılması gerektiği kabul edilmelidir. Sadece bir ihtarda bulunulması veya icra takibi yapılmas1 halinde, bunun bildirilmesinin gerekli olmadığg kanaatindeyim ${ }^{115}$.

Ayrıca bu hükmün bir bütün olarak genel sisteme aykırılık oluşturan yapısı nedeniyle uygulama alanının genişletici değil, daraltıcı bir yorumlama yapılmasının da uygun olacağı kabul edilebilir.

Bildirim külfetinin dava açılmasıyla doğacağını kabul ettiğimizden, bildirimin, davanın ihbarı yoluyla yapılması gerektiği de ortaya çıkmaktadır.

111 KAPANCI, (2014), s. 555; KAPANCI, (2019), m. 61-62, no. 36; BAYSAL, s. 640; YAĞCIOĞLU, s. 401; ÇELİK, m. 73, no. 28; KIRCA, s. 50; KURT, s. 157.

112 KURT, s. 155; YAĞCIOĞLU, s. 396; AŞIK, s. 82.

${ }^{113}$ Karş. YAĞCIOĞLU, s. 393; GÜRPINAR, s. 285; KURT, s. 154.

${ }^{114}$ KIRCA, s. 50.

${ }^{115}$ Bu yönde: KURT, s. 155, dn.74; YAĞCIOĞLU, s. 394. Doktrinde, dava dış1 talep halinde dahi, bu bildirimin yapılmasının gerektiği ileri sürülmüştür. Bkz. KAPANCI, (2014), s. 556; KAPANCI, (2019) m. 61-62, no. 36; DALCI ÖZDOĞAN, s. 222. 
HMK 62 / I gereğince davanın ihbarının yazılı olarak yapılması ve ihbar sebebinin gerekçelerinin bildirilmesi gerekir ${ }^{116}$.

Bildirim külfetine aykırılığın sonucu: Bildirim yapılmazsa, rücu alacağının bağlı olduğu zamanaşımı süresinin (henüz ifa bile yapılmadan önce) işlemeye başlaması gibi garip bir sonuç doğmaktadır. Buna göre, borcun ifası kendisinden istenen müteselsil borçlu, bu durumu diğer müteselsil borçlulara bildirmezse 2 yıllık zamanaşımı süresi, bu bildirimin dürüstlük kurallarına göre yapılabileceği tarihte işlemeye başlar ${ }^{117}$.

Bildirimin dürüstlük kurallarına göre yapılabileceği tarihin tespiti: Bildirimde bulunulmazsa sürenin işlemeye başlaması muğlak bir biçimde düzenlenmiştir ${ }^{118}$. Bunun takdirini rücu talebini inceleyen mahkeme yapacaktır. İsviçre Federal Mahkemesi, Kurt tarafından aktarılan uygulamasıyla, dava açıldıktan sonraki bir ay içinde yapılan ihbarı süresi içinde görmüşken, iki ay sonra yapılan ihbarı ise süresi içinde değerlendirmemiştir ${ }^{119}$.

Bu hükmün uygulanması için ilk olarak kendisinden talepte bulunulan müteselsil borçlu tarafından, diğer borçlulara bildirim yapma imkânının doğması gerekir. Bunun için de, diğer müteselsil borçluların varlığının, kimliğinin ve iletişim bilgilerinin öğrenilmesi gerekir ${ }^{120}$. Ayrıca bildirim külfeti ancak, aleyhine dava açılmayan müteselsil borçlular için mevcuttur.

$\mathrm{Bu}$ bilgilerin öğrenilmesinden itibaren makul süre içinde bildirim yapılmalıdır ${ }^{121}$. Aksi halde Kanunun ifadesiyle rücu alacağının zamanaşımı süresi işlemeye başlar.

Bildirimin her bir müteselsil borçlu için ayrı ayrı değerlendirilmesi gerekir. Mesela 5 müteselsil borçludan birine dava açıldığında, bu kişi diğer müteselsil borçlulardan ikisini öğrendiğinde, bunlara bildirimde bulunmalı, diğer ikisi için ise, bilgi sahibi olmadığından bildirim külfetinin başlamadığı kabul edilmelidir.

\footnotetext{
${ }^{116}$ KURT, s. 155. Farklı gerekçeyle benzer sonuçta: DALCI ÖZDOĞAN, s. 222. Ayrıca bkz. YAĞCIOĞLU, s. 395; ÇELİK, m. 73, no. 30.

117 NOMER, (2011), s. 255.

${ }^{118}$ KURT, s. 156; KAPANCI, (2014), s. 560; DALCI ÖZDOĞAN, s. 221; YAĞCIOĞLU, s. 396; KIRCA, s. 51; 283.

${ }^{119}$ Bkz. KURT, s. 157.

${ }^{120}$ BAYSAL, s. 640; KURT, s. 155; YAĞCIOĞLU, s. 395.

121 YAĞCIOĞLU, s. 396.
} 
Kanaatimce TBK 73 / II hükmü ilk yapılacak kanun değişikliğinde kaldırılmalıdır ${ }^{122}$. Yukarıda da belirtildiği üzere bildirim külfetinin altında yatan sebep, diğer müteselsil borçluların davadan haberdar olmasını sağlayıp, varsa gerekli savunmalarını yapması ve davanın mümkün olan en lehe biçimde sonuçlanmasının sağlanabilmesidir. Bu nedenle bildirimin yapılmamasının yaptırımı, henüz muaccel olmayan rücu alacağının zamanaşımı süresinin başlatılması değil, olsa olsa, bildirimin geç yapılması veya hiç yapılmaması nedeniyle doğan olumsuz sonucun, diğer müteselsil borçlulara yüklenmesinin önlenmesidir ${ }^{123}$.

Fakat bu hüküm mevcut ve yürürlükte olduğuna göre, bunun uygulama alanını daraltıcı bir yorum yapılması uygun olur.

Buna göre ilk olarak, diğer müteselsil borçlu / borçlular, dava açıldığından haberdarsa, kanaatimce bildirimde bulunulmamasının bir sonucu olmamalıdır.

Ayrıca diğer müteselsil borçlular davadan habersiz olsa bile, bildirimde bulunulsaydı da, sorumluluk yönünden hiçbir etki doğmayacak idiyse, rücu zamanaşımı süresi yine bu bildirimin yapılması gereken tarihten başlamakla birlikte, rücu davasının açıldığı tarihte zamanaşımı süresi dolmuşsa, davalının bu yönde bir savunma yapması dürüstlük kurallarına aykırı sayılabilir.

Ayrıca rücu imkânı olan hallerde davanın ihbar edilmemesinin hukuki sonuçları zaten hukukumuzda düzenlenmiş bir konudur. HMK 61 vd hükümlerinde davanın ihbarı kurumu düzenlenmiştir.

HMK 61 / I hükmüne göre: "Taraflardan biri davayı kaybettiği takdirde, üçüncü kiş̧iye ... rücu edeceğini düşünüyorsa, tahkikat sonuçlanıncaya kadar davayı üçüncü kişiye ihbar edebilir."

HMK 64 hükmüne göre: “Ihbar edilen davada verilen hükmün ihbar eden kişiye etkisi hakkında 69 uncu maddenin ikinci fikrası hükmü klyasen uygulanir."

HMK 69 / II: “Fer'̂̀ müdahilin, tarafla rücu ilişkisinde, asıl davadaki uyuşmazlık hakkında yanlış karar verildiği iddiası dinlenilmez. Ancak,

122 DALCI ÖZDOĞAN, s. 222. Hükmün yerinde olmadığı görüşünde: KIRCA, s. 50; KURT, s. 158. Maddenin yerinde bir hüküm niteliği taşıdığı görüşünde: NOMER, (2011), s. 255.

${ }^{123}$ Nitekim TBK 164 / II hükmüne göre, müteselsil borçlu, ortak savunmaları ileri sürmezse, diğerlerine karşı sorumlu olur. Diğer bir ifadeyle, diğerlerine rücu hakkını, ortak savunmayı ileri sürseydi elde edilebilecek lehe sonuç ölçüsünde kaybeder. Bkz. EREN, s. 1350. 
müdahil, zamanında ihbar yapılmadiğı için davaya geç katıldığını veyayanında katıldığı tarafin iddia ve savunma imkânlarını kullanmasını engellediğini ya da kendisince bilinmeyen iddia ve savunma imkânlarının, tarafin ağır kusuru sebebiyle kullanılamadiğını belirterek, yanında katıldı̆̆ı tarafin yargılamayı hatalı yürüttügünü ileri sürebilir."

Görüldüğg̈ gibi, ihbarın yapılmamasının / geç yapılmasının hukuki sonuçları, HMK'da detaylı olarak düzenlenmişken, bunlar görmezden gelinerek rücu zamanaşımının rücu alacağının doğmasından önce işlemeye başlaması gibi bir sonucun kabul edilmesi yerinde olmamıştır.

Fakat mevcut düzenlemelerde, her iki hüküm de birlikte uygulama alanına sahip olabilecektir ${ }^{124}$. Mesela dava açıldığında bildirimde bulunulmazsa, rücu zamanaşımı süresi işlemeye başlar. 2 yıllık bu süre içinde tazminatın tamamı da ödenir ve rücu için dava açılırsa, TBK 73 / II'nin yanında HMK 64'ün yollaması gereğince HMK 69 / II’de uygulanır.

\section{c. TBK 73 hükmüyle getirilen ilkelerin diğer rücu talepleri bakımından da uygulanabilirliğinin incelenmesi}

Yukarıda da belirtildiği gibi, TBK 73 hükmünün sadece haksız fiilden doğan müteselsil borçlulukta, müteselsil borçlular arasında bir sözleşme ilişkisinin bulunmadığı durumda rücu hakkı için uygulanabilir olduğunu kabul etmekteyiz. Fakat bu hükümle getirilen bazı ilkeler, acaba dayanağ 1 başka olan diğer rücu taleplerine kıyas yoluyla uygulanabilir mi?

Uygulanabilir olup olmadığ incelenmesi gereken ilkeler, rücu zamanaşımının borcun kısmen ifasıyla değil, borcun tamamının ifasıyla başlaması ve ifanın istendiğinin diğer müteselsil borçlulara bildirilmesi külfetine aykırılığın sonucuna ilişkin hükümlerdir.

Mesela bir kira sözleşmesinde müteselsilen borçlu olan kiracılardan biri aleyhine ifa davası açıldığında, kiracı bu durumu diğer müteselsil borçluya bildirmezse, rücu talebinin zamanaşımının, bildirimin dürüstlük kurallarına göre yapılabileceği tarihte işlemeye başlaması hükmü uygulanabilir mi? Veya bu örnekte kendisinden ödemede bulunması istenen kirac1, 10.000 TL olan borcun 7.000 TL'sini öderse, borcun tamamını ödemediği için, payından fazla bir miktarda ödemede bulunmuş olsa bile, rücu zamanaşımı süresi henüz işlemeye başlamaz mı?

${ }^{124}$ KAPANCI, (2019), m. 61-62, no. 36. 
Kanaatimce bu iki hükümle getirilen kurallar, genel sistemden sapan istisnai hükümlerdir. Zira zamanaşımının muacceliyetten önce başlaması veya çok küçük bir kısmen henüz ifa edilmediği gerekçesiyle rücu alacağının zamanaşımının başlatılmaması genel olarak doktrinde de eleştirilen düzenlemelerdir. Bu sebeple bunların kapsamının kıyas yoluyla genişletilmesine değil, tam tersine amaca uygun bir yorumla bunların uygulanma alanının daraltılmasına çalışılmasına ihtiyaç vardır. Bu sebeple bu hükümlerin kıyas yoluyla başka rücu hallerine uygulanması mümkün değildir ${ }^{125}$.

Fakat doktrinde, rücu talebinin kanundan doğduğu ve kanunda özel bir rücu zamanaşımı süresi öngörülmeyen hallerde de bu maddede belirtilen sürenin kıyas uygulanabileceği ileri sürülmüştür ${ }^{126}$.

2. Müteselsil borçlular arasında bir sözleşme ilişkisinin olmadığı ve müteselsil borçluluğun haksız fiil dışında bir sebepten kaynaklandığı hallerde rücu talebi

Müteselsil borçlular arasında bir sözleşme ilişkisinin olmadığı ve müteselsil borçluluğun haksız fiil hukuku dışında doğduğu durumlarda rücu talebinin öncelikle hukuki dayanağının tespit edilmesi gerekir.

Müteselsil borçlular arasında bir sözleşmesel ilişki yoksa, aralarında vekaletsiz işgörme veya sebepsiz zenginleşme biçiminde bir hukuki ilişki doğabilir ${ }^{127}$. Bu durumda rücu zamanaşımı süresi de, bu hukuki ilişkilerin bağlı olduğu sürelere tabidir ${ }^{128}$. Hemen belirtelim ki, müteselsil borçlular arasındaki bu hukuki ilişkinin niteliğinin belirlenmesi çalışmamızın kapsamı dışındadır. Bu aşamada sadece, bu ilişkinin, belirlenecek olan hukuki niteliğine bağlı olarak zamanaşımı süresinin de ortaya çıkacağını belirtmekle yetinmeyi uygun görmekteyiz.

Katılmadığımız bir görüşe göre ise, haksız fiil dışı müteselsil borçluluk hallerinde, müteselsil borçlular arasında bir sözleşmesel ilişki de yoksa, rücu zamanaşımı hakkında TBK 73 hükmü uygulanmalıdır ${ }^{129}$. Fakat TBK

\footnotetext{
${ }^{125}$ NOMER, (2011), s. 251; YAĞCIOĞLU, s. 403.

126 ANTALYA, s. 670; ÇELİ, m. 73, no. 4

${ }^{127} \mathrm{Bu}$ durumlar için bkz. KAPANCI, (2019), m. 167, no. 2; KAPANCI, (2014), s. 505 ve s. 514. Bkz. ve karş. ÖZEN, s. 1469 vd; ERDEM, (2010) s. 115.

${ }^{128}$ TEKINAY / AKMAN / BURCUOĞLU / ALTOP, s. 1046.

${ }^{129}$ DALCI ÖZDOĞAN, s. 223.
}

40 Ankara Hacı Bayram Veli Üniversitesi Hukuk Fakültesi Dergisi C. XXIV, Y. 2020, Sa. 4 
73, münhasıran haksız fiile dayalı rücu alacakları için getirilmiş bir hüküm olduğundan ve haksız fiil dışı müteselsil borçlulukta, müteselsil borçlular arasındaki rücu hakkının vekâletsiz iş görme veya sebepsiz zenginleşmeye dayandırılabileceği açık olduğundan, bu yönde bir genelleme doğru değildir.

\section{A. 01.01.2020 Tarihinde Yürürlüğe Giren Rücu Zamanaşımına İlişkin İsviçre Borçlar Kanununun 139 Madde Hükmü}

İsviçre hukukunda haksız fiilde müteselsil sorumluların rücu zamanaşımı konusunda açık bir hüküm 01.01.2020 tarihine kadar yoktu. Bu dönemde Federal Mahkeme, eksik teselsül halinde rücu zamanaşımının, tazminatın ödendiği ve müteselsil sorumlunun öğrenildiği andan itibaren 1 yıl ve zarara yol açan olayın sona erdiği tarihten itibaren 10 yıllık süreye bağlı olduğunu kabul etmekteydi ${ }^{130}$.

İsviçre Borçlar Kanununda yapılan ve 01.01.2020 tarihinde yürürlüğe giren zamanaşımı hukuku revizyonuyla, zamanaşımı hukuku alanında bazı önemli değişiklikler yapılmıştır. Bunlardan biri de, müteselsil borçlulukta rücu zamanaşımına ilişkin OR 139 hükmüdür.

Rücu zamanaşımına ilişkin olarak getirilen bu hüküm, zamanaşımına ilişkin 127-142 maddeleri arasında eklenmiştir. Bu sebeple bu hüküm, sadece haksız fiilde rücu konusunda değil, haksız fiil dışı rücu taleplerinde de uygulanabilecek bir genel hüküm haline getirilmiştir ${ }^{131}$. Hatta OR 129'de geçen, bu kısımda belirtilen zamanaşımı sürelerinin değiştirilemeyeceğine ilişkin hüküm gereğince, sözleşme hukuku alanında rücu zamanaşımının taraf iradesiyle bu hükümden farklı olarak düzenlenemeyeceği de ileri sürülmüştür ${ }^{132}$.

Zamanaşımının düzenlendiği kısım içine eklenen bu yeni maddede, birden fazla kişinin müteselsilen sorumlu olması halinde, alacaklıyı tatmin eden her bir borçlunun rücu talebinin, alacaklının tatmin edildiği ve birlikte sorumlu olanların öğrenildiği günden itibaren 3 yılın geçmesiyle zamanaşımına uğrayacağ düzenlenmiştir ${ }^{133}$.

\footnotetext{
${ }^{130}$ FELLMANN, s. 216; MAERKI, s. 184; DALCI ÖZDOĞAN, s. 216. BGE 133 III 6, E.5.3.

131 VERDE, (2020), s. 180.

${ }^{132}$ VERDE, (2020), s. 181. Aksi görüşte: KARAŞAHIN, s. 752.

133 İsviçre hukukunda tam-eksik teselsül ayrımı varlığını sürdürdüğünden, bu hükmen sadece eksik teselsülde mi, yoksa hem eksik, hem de tam teselsülde mi uygulanacağ farklı görüşler ortaya çıkmıştır. Bkz. FELLMANN, s. 216; PICHONNAZ, s. 742.
} 
Buna göre, müteselsil borçlulukta rücu zamanaşımı süresi 3 yıldır. Bu süre, borcun ödendiği ve müteselsil borçlunun öğrenildiği tarihten başlar ${ }^{134}$. Ayrıca bir üst süre ise öngörülmemiştir ${ }^{135}$.

İsviçre hukukunda bu hükümde bir üst sürenin öngörülmemesi eleştirilmiştir ${ }^{136}$. Buna göre zarar gören alacaklı bile, zarara yol açan fiil tarihinden itibaren belli bir süre içinde faili ve zararı öğrenememiş olsa bile tazminat alacağı zamanaşımına uğrarken, rücu talebinde müteselsil borçlunun kimliğinin öğrenilememesi halinde rücu talebinin üst süre sınırı olmaksızın talep edilebileceğinin kabul edilmesi doğru değildir. Buna göre, teorik olarak bu hüküm karşısında, zararın tamamını karşılayan müteselsil sorumlu, diğer müteselsil sorumlunun varlığın ve kimliğini mesela bu tarihten itibaren 30 y1l sonra öğrenirse, bu tarihten itibaren 3 y1l içinde rücu için başarılı biçimde dava açabilecektir.

Fakat doktrinde bu maddeyle sadece kısa süreye ilişkin bir hüküm getirdiği, uzun süre yönünden ise bir düzenleme bulunmaması nedeniyle bu konudaki boşluğun, 10 yıllık üst sürenin uygulanmasıyla doldurulması gerektiği ve fakat bu 10 yıllık sürenin de, tazminatın ödendiği tarihten başlatılmasının uygun olacağı ifade edilmiştir ${ }^{137}$.

\section{HALEFIYETE DAYALI GENEL RÜCU HAKKININ TABI OLDUĞU ZAMANAŞIMI SÜRESI}

\section{A. Genel Olarak}

Gerek TBK 62 / II, gerekse de TBK 168 / I hükmünde, iç ilişkideki payından fazla bir tutarda ifada bulunan müteselsil borçlunun yaptığı ifayla borcun sona ermeyeceği, tersine ifada bulunan müteselsil borçlunun alacakliya halef olacağı açıkça düzenlenmiştir ${ }^{138}$. Buna göre müteselsil borçlu, yaptığı ifa

\footnotetext{
${ }^{134}$ Sürenin başlaması için öğrenmenin arandığı, gerekli özenin gösterilmesi halinde diğer müteselsil sorumluların öğrenilebilmesinin mümkün hale gelmesinin yeterli olmadığı yönünde: FELLMANN, s. 216.

${ }^{135}$ MAERKI, s. 185; Bu yönde bir üst sürenin öngörülmemiş olmasının bilinçli olmadığı, bir boşluk bulunduğu görüşünde: FELLMANN, s. 217. ROTHENBERGER, s. 98.

${ }^{136}$ ROTHENBERGER, s. 98.

${ }^{137}$ ROTHENBERGER, s. 98; FELLMANN, s. 217. Hatta fiil suç teşkil ediyorsa, üst sürenin 10 yıl olarak değil, ceza zamanaşımı süresi kadar olması gerektiği de ileri sürülmüştür. Bkz. FELLMANN, s. 217; BERGAMIN, s. 39.

${ }^{138}$ Doktrinde, kanun yapma tekniği açısından, TBK 62 / II fikrası hükmünün gereksiz bir tekrar niteliğinde olduğu haklı olarak belirtilmiştir. Zira TBK 61 / I'le yapılan yollama nedeniyle,
} 
nedeniyle rücu hakkına sahip olduğu ölçüde, alacaklının haklarına da halef olur.

Halefiyetin hukuki sonucu, ifada bulunan müteselsil borçlunun, alacaklının yerine geçip, diğer müteselsil borçlulara, alacaklının halefi olarak temel ilişkideki borçluluk hükümlerine göre rücu edebilmesidirr ${ }^{139}$.

$\mathrm{Bu}$ halefiyetin bir sonucu, halefiyete dayalı genel rücu alacağının bağl1 olduğu zamanaşımı süresinin, asıl borcun bağlı olduğu zamanaşımı süresiyle aynı olmasıdır ${ }^{140}$. Buna göre asıl borcun bağlı olduğu zamanaşımı süresi mesela 5 yıl ise, halefiyete dayalı rücu hakkının bağlı olduğu zamanaşımı süresi de 5 yıldır.

Halefiyete dayanan genel rücu hakkının, özel rücu hakkıyla sınırlandığını belirtmiştik $^{141}$. Bunun zamanaşımı yönünden etkisi şu örnekte görülebilir:

Bir kamu kurumuna belli bir miktar malı tedarik işini üstlenen (A) ve (B)'den müteşekkil adi ortaklığın, kesin hesap aşamasında fazladan aldığ1 ortaya çıkan parayı iade etme borcundan (A) ve (B) müteselsil olarak sorumludurlar (TBK 638 / III). Bu sorumluluğun bağlı olduğu zamanaşımı süresi, satış sözleşmesinden doğan alacaklara bağlı olduğundan 10 y1ldır ${ }^{142}$.

TBK 62 / II hükmünü fazlasıyla karșılayan TBK 167 / II ve 168 / I zaten müteselsil sorumluluk halinde de uygulanacaktır. KILIÇOĞLU, (2014), s. 463; OĞUZMAN / ÖZ, (2017), no.863; KILIÇOĞLU, (2007), s. 172; KURT, s. 151, dn. 56; GÜRPINAR, 283; NOMER, (2011), s. 249; ÇELIK, m. 73, no. 10.

${ }^{139}$ EREN, s. 1355; ACAR, (2019), m. 127, no. 38; KAPANCI, (2014), s. 362; NOMER, (2011), s. 250; ŞAHIN CANER, s. 278; VON TUHR, s. 488 vd; YAĞCIOĞLU, s. 402.

${ }^{140}$ ROTHENBERGER, s. 76 ve 97; TERCIER / PICHONNAZ / DEVELİOĞLU, no.1 646; GAUTSCHI, s. 149; TEKINAAY / AKMAN / BURCUOĞLU / ALTOP, s. 1045; KILIÇOĞLU, (2014), s. 506; KILIÇOĞLU, (1979), s. 13 ve özellikle s. 135; NOMER, (1997), s. 251; ACAR, (2019), m. 127, no. 49; KAPANCI, (2014), s. 540; KAPANCI, (2019), m. 61-62, no. 38; KAPANCI, (2019), m. 168, no. 39; DALCI ÖZDOĞAN, s. 224; ÇELIK, m. 73, no. 17.

${ }^{141}$ Aksi görüşteki yazarlara göre ise, böyle bir sınırlama söz konu değildir. Bkz. DALCI ÖZDOĞAN, s. 225.

${ }^{142}$ YHGK 14.03.2012, E. 2011/13-748, K. 2012/140: “Dava, fazladan yapıldığ ileri sürülen ödemenin istirdadı istemine ilişkindir. Davacı şirket; taraflar arasındaki sözleşmenin ayakta ve geçerli olduğu bir dönemde, davalı idareye birinci 6 aylık dönem ile üçüncü 6 aylık dönemin sonunda fazla ödemede bulunduğunu ileri sürerek, eldeki istirdat davasını açtığlna göre, taraflar arasındaki hukuki ilişkinin çözümünde aralarındaki sözleşmenin dikkate alınması zorunludur. Taraflar arasındaki sözleşme hükmü, edimlerin karşıllklı olarak tür ve miktarını tespit etmekle birlikte, bu sinırlama aynı zamanda taraflar arasında örtülü olarak, karşı tarafa geçeceği öngörülmeyen malvarlı̆̆l değerlerinin iadesi yükümlülüğünü de içerdiğinden, davact şirketin, sözleşmenin feshedildiği tarihte yapılacak bir kümülatif hesaplama sonucu, davaliya fazladan yaptığı bir ödemenin varlı̆ğnın tespiti halinde, bu 
Alacaklı kamu kurumu, sadece (A)'ya karşı 8. yılda dava açarsa, bu davayla kesilen zamanaşımı, (B) yönünden de etki doğurur. Dava 4 yıl sürmüş ve bu sürenin sonunda (A) bu paranın tamamını ödemek zorunda kalmışsa, iç ilişkideki payından fazlası için yaptığı ödemeyi (B)'den isteyebilir. $\mathrm{Bu}$ ifayla (A), alacaklı kamu kurumuna halef olduğundan, halefiyete dayalı rücu alacağı da (temel ilişkideki zamanaşımı süresine bağlı olacağından) 10 yıllık zamanașımı süresine tabi olacaktır. Fakat (A) ile (B), adi ortaklığın ortakları olduğundan, bunların birbirlerinden olan alacakları TBK 147 / I, b.4 gereğince 5 yıllık zamanaşımına tabidir. Bu sebeple, bu olayda halefiyete dayalı genel rücu hakkının da 5 yıllık süre içinde kullanılması gerekir.

Halefiyete dayalı genel rücu talebi bakımından çözümlenmesi gereken bir sorun da şudur: (B1) ve (B2), (A)'ya karşı bir haksız fiil nedeniyle müteselsil borçlu olsun. Zarar gören (A), fiili, zararı ve (B1)'in sorumluluğunu öğrendiği halde ona iki yıl içinde dava açmamış, fakat 3. yılda bu zarardan (B2)'nin de müteselsil sorumlu olduğunu öğrenip ona karşı tazminat davası açmışsa hukuken cevaplanması gereken bazı sorular sorulabilirir ${ }^{143}$ :

Birinci Soru: (A)'ya karşı olan borcu zamanaşımına uğramış bulunan (B1), (B2)'nin (A)'ya tüm tazminatı̈ ödemesi halinde,(B2)'nin halefiyete dayalı rücu talebi karşısında, kendisinin (A)'ya karşı olan borcunun zamanaşımına uğradığı, bu sebeple rücu alacağının kendisine karşı ileri sürülemeyeceği savunmasinda bulunabilir mi?

(B2) yaptığ1 ifayla, (A)'nın yerine geçer. Bu durumda (B1), (A) karş1 ileri sürebileceği savunmaları, (B2)'ye karş1 da ileri sürebilir ${ }^{144}$. Bu sebeple bu soruya vereceğimiz cevap, (B1)'in kendi borcunun (A)'ya karş1 zamanaşımına uğraması halinde, bu savunmayı halefiyete dayalı rücu talebi için de kullanabileceği yönündedir.

Fakat Kapancı'nın da haklı olarak ifade ettiği gibi, müteselsil borçlular arasındaki özel hukuki ilişkiye dayalı rücu imkânında farklı bir sonucun kabulü gerekir ${ }^{145}$. Buna göre, bu olayda (B2)'nin rücu talebi, iç ilişkiye dayalı özel rücu talebine dayandırılırsa ve bunun zamanaşımı süresi henüz

miktarı sözleşme hukuku çerçevesinde davalı idareden istirdada hakkı bulunduğunun kabulü gerekmektedir." (www.kazanci.com.tr, erişim: 01.07.2020).

${ }^{143}$ Her bir müteselsil borçlunun bağlı olduğu zamanaşımı süresi diğerinden bağımsız olarak işleyeceğinden, bu olayda (B2) yönünden bir zamanaşımı savunmasına imkân yoktur.

144 KAPANCI, (2014), s. 363; DALCI ÖZDOĞAN, s. 225.

${ }^{145}$ KAPANCI, (2014), s. 264, dn. 1094. Aynıca bkz. KAPANCI, (2019) m. 166, no. 120. 
geçmediyse, (B1), (B2)'ye karşı böyle bir savunma yapamayacaktır. Mesela (B1) ve (B2), bir adi ortaklığın ortaklarıysa ve bu haksız fiile dayalı zarar, adi ortaklığın bir çalışanı tarafından işlenmişse, tazminatın tamamının (B2) tarafindan ödenmesi halinde iç ilişkiye dayalı özel rücu talebi TBK 627 / I hükmüne dayanacağından, (B1), (B2)'ye karşı zamanaşımı savunmasında bulunamayacaktır ${ }^{146}$. Yeter ki, özel ilişkide dayalı rücu talebinin bu olayda bağlı olduğu 5 yıllık zamanaşımı süresi geçmemiş olsun.

Görüldüğü gibi rücu talebinin müteselsil borçlular arasındaki özel ilişkiye dayanması halinde, rücu talebinin halefiyet yoluyla intikal eden hakla bir ilişkisi olmadığından, yukarıda açıklanan durumda (B1),(B2)'ye karşı zamanaşımı savunmasında bulunamayacaktır. Haksız fiilde rücu talebinin dayağı (müteselsil borçlular arasında ayrıca bir sözleşme yoksa) TBK 62 olacağından, bu özel rücu talebine dayanılması halinde, halefiyetten bağımsız olarak, yeni bir zamanaşımı süresi başlayacaktır. $\mathrm{Bu}$ sebeple bu durumda da açıklanan ihtimalde (B1)'in (B2)'ye karşı bu yönde bir savunma yapması mümkün olmayacaktır.

Doktrinde ilk soruya olumsuz cevap veren yazarların tartışmaya açtığ1 ikinci bir sorun daha bulunmaktadır. Verilen olayda (B1)'in; (B2)'nin rücu talebi karşısında, kendisinin (A)'ya karşı olan borcunun zaten zamanaşımına uğradığını; bu sebeple (A)'nın halefi olan (B2)'nin rücu talebinin de zamanaşımına uğradığını def'i olarak başarılı biçimde ileri sürebileceği kabul edilirse; acaba (B2), aleyhine (A) tarafindan dava açılması aşamasında, o tarihte (B1)'in borcunun zamanaşımına uğradığı gerekçesiyle, kendisinin borcun tamamından değil, sadece kendi payı ölçüsünde sorumlu olması gerektiği yönünde bir savunma yapabilir miydi?

Yukarıda verdiğimiz cevapta, (B1)'in borcu (A)'ya karşı zamanaşımına uğrasa bile, borcun tamamını ödeyen (B2)'nin iç ilişkiye dayalı rücu talebi karşısında (B1) sorumlu olacağına göre, (B2)'nin bu soruda açıklanan konuyla ilgili bir savunmada bulunması ihtiyac1 da yoktur. Fakat bazı yazarlarca, bir önceki soru sadece halefiyete dayalı rücu kapsamında değerlendirildiğinden, (B2)'nin dış ilişkide bu savunmaya dayanıp dayanamayacağı ayrıca tartışılmıştır.

İlk soruya, açıkladığımız görüşten farklı cevap veren yazarlara göre, bu ikinci soruya olumsuz cevap verilirse, (B2) borcun tamamını üstlenmek

${ }^{146}$ Aynı sonuçta: DALCI ÖZDOĞAN, s. 226 ve özellikle s. 229. 
zorunda kalacaktır ${ }^{147}$. Fakat bunun sebebi, (B1)'e karş1 zamanında harekete geçmeyen (A)'nın pasif davranışı olacaktır. Bu davranışın olumsuz sonucunun (B2)'ye yüklenmesi adil olmaz. Bu sebeple, bazı dayanaklar kullanılarak, (B2)'nin dış ilişkide de bu savunmayı yapabilmesi mümkün olmalıdır. Bunun dayanakları olarak kullanılabilecek hükümlerin başında TBK 166 / III hükmü gelmektedir. Nasıl ki, bu hükme göre alacaklı müteselsil borçlulardan birini ibra ettiğinde; diğer müteselsil borçlular da, ibra edilen müteselsil borçlunun iç ilişkideki borca katılma payı ölçüsünde borçtan kurtuluyorsa, alacaklının ihmali nedeniyle borçlulardan biri hakkında zamanaşımı gerçekleştiğinde, diğer müteselsil borçlular da, bu hususun def'i olarak ileri sürülmesi halinde, bu kişinin iç ilişkideki payı ölçüsündeki kısım talep edilemez olarak değerlendirilmelidir. Buna göre, aleyhine dava açılan müteselsil borçlu, (A)'nın (B1)'den olan alacağının zamanaşımına uğradığını def'i olarak ileri sürmek suretiyle bu etkiden yararlandırılmaktadır ${ }^{148}$.

Doktrinde Dağdelen ${ }^{149}$, bu sonucun kabulünde, TBK 168 / II hükmünden yararlanmaktadır. Buna göre alacaklı, borçlulardan birinin durumunu diğeri aleyhine iyileştirirse bunun sonuçlarına katlanır. Bu hükümden yola çıkılarak, alacaklının, borçlulardan biri için zamanaşımının geçmesine göz yumması, aslında diğer borçlular aleyhine birinin durumunun iyileştirilmesi niteliği taşır. $\mathrm{Bu}$ sebeple bu durumda kendisine başvurulan müteselsil borçlu, bu yönde bir savunma yapıp, sorumluluğunun daha az olması gerektiğini ileri sürebilir.

Fakat tekrar belirtelim ki kabul ettiğimiz görüş gereğince, rücu talebi halefiyete değil de, doğrudan müteselsil borçlular arasındaki özel hukuki ilişkiye dayandırılırsa, müteselsil borçlulardan birinin borcu dış ilişkide zamanaşımına uğramış bile olsa, diğer müteselsil borçlu buna dayanıp sorumluluğunun daraldığını ileri süremez ${ }^{150}$. Zira bu durumda rücu talebi müteselsil borçlular arasındaki özel hukuki ilişkiye dayanmakta olup, bunun halefiyetle intikal eden alacakla bir ilişkisi yoktur. Bu sebeple kabul ettiğimiz görüş̧te ikinci sorunun sorulması bile gereksizdir.

\footnotetext{
${ }^{147} \mathrm{Bu}$ durumda doğrudan borcun miktarının azalması gerektiği görüşünde: TEKINAY / AKMAN / BURCUOĞLU / ALTOP, s. 307; ERDEM, (2010), s. 119; CANPOLAT, s. 77.

Bu konudaki detaylı açıklamalar için bkz. YAĞCIOĞLU, s. 255.

${ }^{148} \mathrm{Bu}$ konuda farklı görüşler için bkz. YAĞCIOĞLU, s. 255.

149 DAĞDELEN, s. 112.

${ }^{150}$ Karş. ŞAHIN CANER, s. 224; ÇANDARLI, s. 1293.
} 


\section{B. Özel Rücu Talebinin Hem İçerik, Hem De Zamanaşımı Yönünden Halefiyete Bağlı Genel Rücu Talebini Sınırlaması}

Genel rücu talebi, özel rücu talebinden daha geniş veya dar kapsamlı olabilir. $\mathrm{Bu}$, hem içerik, hem de zamanaşımı gibi yönlerden geçerlidir.

Fakat taraflar arasındaki özel hukuki ilişkinin getirdiği sınırlamalar, halefiyete dayalı genel rücu hakkı için de geçerlidir ${ }^{151}$. Bu konuyla ilgili açıklama, şu örnek üzerinde verilebilir:

İnşaat firması (F); (A) ve (B)'den oluşan adi ortaklıktan inşaat malzemesi satın alır. Bu malzemelerin teslimi sırasında satıcının çalışanı (Ç), özensiz (kusurlu ve hukuka aykırı) davranışları sonucunda (F)'nin diğer mal varlığı değerlerinde bir zarara neden olur. Bu olayda (A) ve (B), bu zarardan hem haksız fiil hükümlerine göre (TBK 66), hem de sözleşmeye aykırılık hükümlerine göre (TBK 116) sorumludur. Sözleşmeye aykırılığa dayalı zararın tazmini talebi, TBK 146 gereğince 10 yıllık zamanaşımı süresine tabidir. Mesela (A) bu zararın tamamını 7. yılda tazmin ederse, bu ifasıyla alacaklının haklarına halef olur ve bu tarihten itibaren 10 yıllık süre içinde rücu talebini müteselsil borçlu (B)'ye karşı (payı oranında) ileri sürebilir. Fakat bu olayda (A) ile (B) arasında bir adi ortaklık sözleşmesi bulunmaktadır. Adi ortaklıkta ortaklar arasında doğan tüm borçlar 5 yıllık zamanaşımı süresine tabidir. Bu sebeple, genel rücu talebine ilişkin zamanaşımı süresinin, özel rücu talebinin daha kısa olan zamanaşımı süresiyle sınırlandığını kabul etmek gerekir ${ }^{152}$.

Fakat halefiyete dayalı rücu hakkı zamanaşımına uğramış olsa bile, müteselsil borçlular arasındaki hukuki ilişkiden doğan talep zamanaşımına uğramamışsa, buna göre rücu talebinin ileri sürülmesi mümkündür ${ }^{153}$.

Halefiyete dayalı olarak rücu hakkının kullanan müteselsil borçluya karşı davalı, özel rücu hakkının kapsamının daha dar olduğunu veya zamanaşımına uğradığı iddia ve ispat ederek, bu talebe karşı koyabilir ${ }^{154}$. Bu yönüyle genel rücu hakkının kullanılması halinde, özel rücu hakkından doğan savunmalarının iddia ve ispat yükü davalıdadır ${ }^{155}$.

\footnotetext{
${ }^{151}$ Bkz. AKINTÜRK, s. 223; KAPANCI, (2014), s. 366, s. 371; KAPANCI, (2019), m. 61-62, no. 34.

${ }^{152}$ KAPANCI, (2014), s. 391, s. 540 ve özellikle s. 550.

153 KAPANCI, (2014), s. 540.

154 AKINTÜRK, s. 223.

${ }^{155}$ KAPANCI, (2014), s. 391; KAPANCI, (2019), m. 61-62, no. 34.
} 


\section{Halefiyete Dayalı Rücu Hakkının Bağlı Olduğu Zamanaşımının İşlemeye Başlaması ve TBK 155 / I Hükmünün Etkisi}

Yukarıda, alacağın, payından fazla miktarda ifada bulunan müteselsil borçluya intikal etmesi nedeniyle, alacaklı için geçerli olan zamanaşımı süresinin, halefiyete dayalı rücu talebi için de geçerli olduğunu belirtmiştik. $\mathrm{Bu}$ sebeple zamanaşımı, halefiyetin gerçekleştiği anda hangi durumdaysa, o haliyle intikal eder. Halefiyetin gerçekleştiği anda, mesela 5 yıllık zamanaşımının 3. yılı geçmişse, rücu alacağının 2 yıl içinde ileri sürülmesi gerekir. Bu haliyle rücu hakkı yönünden zamanaşımı bağlamında dezavantajlı bir durum ortaya çıkmaktadır.

Fakat bu aşamada bir hükmün özel olarak ele alınması gerekir: TBK 155 / I.

TBK 155 / I hükmüne göre, zamanaşımı müteselsil borçlulardan birine karşı kesilince, diğer müteselsil borçlulara karşı da kesilmiş olur. Kanunda zamanaşımının kesilmesi sebepleri yönünden bir sınırlama yapılmamıştır. $\mathrm{Bu}$ sebeple Kanunun lafzından yola çıkılarak, borçlulardan birinin borcu ikrar etmesi halinde de zamanaşımının tüm müteselsil borçlular yönünden kesileceği doktrinde hâkim görüş olarak ileri sürülmektedir ${ }^{156}$.

156 VON TUHR, s. 798; BUCHER, s. 495; NOMER, (2015), s. 419; ERDEM, (2010), s. 340. Hâkim görüşe ilişkin literatür için bkz. DALCI ÖZDOĞAN, s. 204, dn.711.

Doktrinde bazı yazarlarca, bu maddenin lafzından yola çıkılarak, farklı bir sonuca ulaşılmasının da mümkün olduğu da ileri sürülmüştür. Buna göre hükümde geçen borçlulardan birine karşı ibaresi nedeniyle, zamanaşımının ancak dışardan bir hareketle kesilmesi halinde bunun diğer müteselsil borçlular yönünden etkili olacağı anlamının çıkarılabileceği savunulmuştur. Ayrıca TBK 165 hükmünde, müteselsil borçluların bireysel davranışlarıyla, diğer müteselsil borçluların durumunu ağırlaştıramayacağı kuralı getirildiğine göre, zamanaşımının, borçlunun bireysel davranışıyla (ikrar, ifa) diğerleri için de kesildiğini kabul etmenin, bu kurala aykırı olduğu, bu sebeple TBK 155 / I hükmünün, TBK 165 ile uyumlu olacak biçimde yorumlanması gerektiği iddia edilmiştir.

Bu sebeple bu görüş gereğince, TBK 155 hükmünde geçen kuralın, amaca uygun bir sınırlama yapılmak suretiyle, zamanaşımının sadece alacaklının fiiliyle kesilmesi halinde bunun diğer müteselsil borçlular yönünden etki doğuracağı biçiminde yorumlanması uygun olur. Bkz. TEKINAY / AKMAN / BURCUOĞLU / ALTOP, s. 1058; AKINTÜRK, s. 204; DALCI ÖZDOĞAN, s. 203; ŞAHIN CANER, s. 234; GAUTSCHI, s. 132; TERCIER / PICHONNAZ / DEVELIOĞLU, no.1581; ÇANDARLI, s. 1294.

Bu görüşe ilişkin literatür için bkz. DALCI ÖZDOĞAN, s. 20, dn.716.

Kanaatimce bu görüş yerindedir. Böylece bir müteselsil borçlunun kendi fiiliyle diğer müteselsil borçlunun durumunu ağırlaştırmaması ilkesi de tam olarak uygulanmış olacaktır. Aksi kanaatte: ERDEM, (2010), s. 341; ERDEM, (2019), m. 155, no. 6.

İsviçre Borçlar Kanununda yapılan ve 01.01.2020 tarihinde yürürlüğe giren zamanaşımı hu- 
Doktrinde haklı olarak eleştirilse de ${ }^{157}$, yürürlükte olan bu hükmün, hâkim görüşe bağlı kalındığında halefiyete dayalı rücu zamanaşımı konusundaki hukuki sorunları ortadan kaldırdığı ileri sürülmüştür ${ }^{158}$.

TBK 154 hükmünde, borçlunun ikrarının, kısmi ifasının veya borca ilişkin teminat göstermesi ile alacaklının dava veya icra takibine başlamasının ya da alacağını defi yoluyla ileri sürmesinin zamanaşımını keseceği düzenlenmiştir.

kuku reformuyla bu hüküm değiştirilmiştir. OR 136 hükmünde yapılan değişiklikle, zamanaşımının kesilmesinin, diğer müteselsil borçlular yönünden de etkili olabilmesi, zamanaş1mının kesilmesinin alacaklının fiilinden kaynaklanmasına bağlanmıştır. Bkz. FELLMANN, s. 219; VERDE, (2019), s. 129; VERDE, (2020), s. 183.

Bu sebeple müteselsil borçlulardan birinin ikrarı, İsviçre hukukunda, diğer müteselsil borçlular yönünden zamanaşımını artık kesmeyecektir. Hükümde yapılan değişiklikler özetle şöyledir:

Birinci fikra: Zamanaşımı, müteselsil borcun veya bölünemez borcun borçlularından biri için kesildiğinde, zamanaşımının kesilmesi alacaklının fiiline dayanıyorsa, zamanaşımı diğer müteselsil borçlular ve bölünemez borcun diğer borçluları yönünden de kesilmiş olur.

İkinci fikra: Zamanaşımı, asıl borçluya karşı kesildiğinde, zamanaşımının kesilmesi alacaklının fiiline dayanıyorsa, kefile karşı da kesilmiş olur.

Üçüncü fikra: Zamanaşımı kefile karşı kesilince, asıl borçluya karşı kesilmiş olmaz.

Dördüncü fikra: Sigortacıya karşı doğrudan talep hakkının bulunduğu hallerde; zamanaşımı sigortacıya karşı kesilince, ası1 borçlu yönünden de; asıl borçluya karşı kesilince sigortacıya karş1 da kesilmiş olur.

Bu sonuncu fikraya göre ortaya çıkan etkinin, sadece sigortacının sorumluluk limiti için söz konusu olabileceği kabul edilmektedir. Bkz. FELLMANN, s. 220; VERDE, (2020), s. 183.

157 TEKİNAY / AKMAN / BURCUOĞLU / ALTOP, s. 1057; EREN, s. 927, s. 1352; KAPANCI, (2014), s. 32, s. 156; KIRCA, s. 44; DALCI ÖZDOĞAN, s. 202; ŞAHİN CANER, s. $232 \mathrm{vd}$.

158 KAPANCI, (2014), s. 545.

Tekinay tarafından savunulan ve yukarıda açıklanan, katıldığımız görüş kabul edilirse, müteselsil borçlulardan birinin borcu ikrar etmesi veya ifa etmesi, diğer müteselsil borçlular yönünden zamanaşımını kesmeyeceğinden, halefiyete dayalı rücu aşamasında ifada bulunan borçlu için önemli bir dezavantaj ortaya çıkacağı doktrinde bazı yazarlarca ileri sürülmüştür. Bu sebeple hükmün hâkim görüş doğrultusunda algılanmasının, rücu alacağı yönünden zamanaşımı sorunlarını çözeceği ifade edilmiştir. Bkz. ve karş. ERDEM, (2010), s. 117, 341; KAPANCI, (2014), s. 155, dn. 706.

Fakat kanaatimce bu olumsuzluk sadece halefiyet yönünden ortaya çıkar. Müteselsil borçlular arasındaki özel ilişkiye dayalı rücu hakkının bağlı olduğu zamanaşımı süresi, zaten (kural olarak) alacaklının tatmin edilmesiyle başlayacağından, alacaklının tatmin edilmesi anından çok kısa bir süre sonra rücu alacağının zamanaşımına uğramış olması gibi bir risk de ortaya çıkmayacaktır. 

başlar.

Bilindiği gibi zamanaşımı kesilince ${ }^{159}$, süre yeniden sıfırdan işlemeye

TBK 154 ile 155 / I birlikte değerlendirildiğinde konumuzla ilgili şu sonuçlar ortaya çıkmaktadır:

1. Müteselsil borçlulardan biri aleyhine dava / takip açılınca, diğer müteselsil borçlular yönünden de zamanaşımı kesilirr' ${ }^{160}$.

2. Hâkim görüșe göre müteselsil borçlulardan biri alacaklıya kısmen veya tamamen ifada bulunursa, zamanaşımı diğer müteselsil borçlular yönünden de kesilir. Borcun ifası, borcun ikrarı anlamına geleceğinden, zamanaşımının kesildiğini kabul etmek uygun olur ${ }^{161}$.

Buna göre, hâkim görüş benimsenirse müteselsil borçlulardan birinin ifada bulunmasıyla, borcun ikrarı gerekçesiyle zamanaşımı tüm borçlular için kesilir ve bu ifayla bu borçlu, alacaklının yerini alır. Bu sonucun kabulünde, zamanaşımı sürelerinin tüm borçlular için hangi seviyede olduğunun bir önemi de yoktur ${ }^{162}$.

Müteselsil borçlulardan biri, ifada bulunduğunda alacaklıya halef olduğuna göre, bu borçlu, halefiyete dayalı rücu alacağ 1 için, bu tarihten itibaren asıl borç için geçerli süre içinde ${ }^{163}$ rücu alacağını ileri sürmezse, sonradan zamanaşımı savunmasıyla karşılaşabilecektir.

159 Zamanaşımının kesilmesi, ancak zamanaşımının işlemeye başlamas ile zamanaşımı süresinin henüz dolmadığı dönemde söz konusu olabilir. Bu sebeple muacceliyetten önceki veya zamanaşımı süresinin dolmasından sonraki ikrar zamanaşımını kesen sebep olarak nitelendirilemez. Müteselsil borçlulardan birinin, kendisi yönünden zamanaşımının dolmasından sonra ifada bulunması halinde, bu ifayla zamanaşımı diğer borçlu yönünden kesilmiş sayılamaz. KAPANCI, (2014), s. 157.

${ }^{160}$ Mesela (ihtiyari veya zorunlu) sorumluluk sigortalarında, TTK 1478 gereğince zarar görenin doğrudan sigorta şirketine başvurma hakkı bulunduğundan, zarar veren ile sigorta şirketinin, zarar gören karşısında müteselsil borçlu olduğu ortaya çıkmaktadır. Bu sebeple, zarar görenin sadece zarar verene dava açması halinde, sigorta şirketi yönünden de zamanaşımı süresi kesilmiş olacaktır. Elbette bunun tersi de geçerlidir.

${ }^{161}$ KAPANCI, (2014), s. 157; KAPANCI, (2019), m. 168, no. 39; OĞUZMAN / ÖZ, (2017), no. 1433; ERDEM, (2010), s. 117.

162 KILIÇOĞLU, (1979), s. 137; KAPANCI, (2014), s. 157. Fakat zamanaşımı diğer müteselsil borçlu yönünden geçmişse, bu ifayla zamanaşımı diğer borçlu yönünden kesilmiş olmaz. KAPANCI, (2014), s. 545.

${ }^{163}$ Yargıtay bu zamanaşımı süresinin daima 10 yıl olacağını kabul etmektedir. Bkz. YHGK, 28.11.1979, 1978 / 15-260 E, 1979 / 141 K. (www.kazanci.com.tr, erişim: 01.07.2020). DALCI ÖZDOĞAN, s. 217. 
Buna göre, halefiyete dayalı rücu alacağı yönünden, borçlulardan birinin ifada bulunmasıyla borç ikrar da edilmiş sayılacağından, zamanaşımı kesilecektir. Bu sebeple, müteselsil borçlunun yaptığı ifa için diğer müteselsil borçlulara rücu etmesinde, yaptığı ifadan itibaren asıl borç için geçerli olan zamanaşımı süresi içinde alacağını dava / takip yoluyla işleme koymaması halinde, diğer müteselsil borçlunun zamanaşımı savunmasıyla karşılaşabilir ${ }^{164}$.

Müteselsil borçlu kısmi ifada bulunsa (fakat bu tutar iç ilişkideki payını aşıyorsa) yine de bu tarihten itibaren rücu alacağı muaccel olur ve zamanaşımı sıfırdan işlemeye başlar ${ }^{165}$.

\section{MÜTESELSİL BORÇLULARIN RÜCU TALEBINNDE İKİNCILL SORUMLULUĞUNUN ZAMANAŞIMI SÜRESI}

En az üç müteselsil borçlunun bulunduğu durumlarda rücu aşamasında ortaya çıkacak her biri birbirine bağlı üç sorun vardır.

1. Rücu aşamasında teselsül var mıdır?

TBK 167 / II, c.2 gereğince rücu alacağında müteselsil borçluluk söz konusu değildir. Bu sebeple, rücu edilebilecek birden çok müteselsil borçlu varsa, bunların sorumluluğu paylıdır.

Mesela üç kişi 30.000 - TL'lik bir borçtan müteselsilen sorumluysa ve bunlardan biri olan (A) borcu tamamını ödemişse, (iç ilişkideki paylarının da eşit olduğunu kabul edersek) payından fazla kısım olarak ödediği 20.000 TL'yi diğer müteselsil borçlulardan (B ve C'den) paylı olarak ödemelerini isteyebilir (TBK 167 / II).

Rücu talebinde paylı sorumluluk söz konusu olduğundan, rücu alacağı yönünden zamanaşımının bunlardan biri için kesilmesi, diğerleri için de kesilme sonucunu doğurmaz ${ }^{166}$. Diğer bir iadeyle, TBK 155 / I gereğince zamanaşımı müteselsil borçlular yönünden kesilince, diğerleri yönünden de kesilmiş sayılır hükmü, rücu talebinde teselsül söz konusu olmadığından uygulama alanı bulmaz ${ }^{167}$.

\footnotetext{
${ }^{164}$ Bkz. EREN, s. 1354; KAPANCI, (2014), s. 544.

${ }^{165}$ KAPANCI, (2014), s. 544.

166 Bkz. EREN, s. 1354.

${ }^{167}$ Zamanaşımının kesilmesine ilişkin diğer tüm hükümler, rücu borçluları için geçerlidir. Mesela rücu borçlularından biri, borcunu ikrar ederse, ona karşı icra takibine girişilirse (veya zamanaşımını kesen diğer sebepler gerçekleşirse) zamanaşımı sadece onun yönünden kesilmiş olur.
} 
2. Rücu aşamasında teselsül söz konusu olmadığına göre, ifada bulunan müteselsil borçlunun, bir müteselsil borçludan payını alamamasının olumsuz sonucu kimin üstüne kalacaktır?

Yukarıda örnekte (A)'nın, (B) ve (C)'ye yöneltebileceği 10'ar bin TL'lik bu rücu alacağının bağlı olduğu zamanaşımı süresi (sorumluluğun haksız fiilden kaynaklandığını kabul edersek) TBK 73 hükmüne tabidir. Buna göre, borcun tamamının ödendiği ve diğer müteselsil borçluların öğrenildiği tarihten itibaren 2 yıl ve her halükarda tazminatın tamamının ödendiği tarihten itibaren 10 y1l içinde bu yönde hukuki girişimde bulunmazsa, rücu alacağ1 zamanaşımına uğrar.

(A)'nın, bu iki ylllık süre içinde, hem (B), hem de (C) aleyhine, 10.000'er TL için rücu davası açtığını kabul edelim. 3 yıl süren davanın sonunda (A) davaların ikisini de kazanır ve (B), payı olan 10.000 TL'yi öder. Fakat (A) yaptığı icra takibi sonucunda (C)'den hiçbir tahsilat yapamaz ve alacağı aciz belgesine bağlanır.

TBK 167 / III hükmüne göre bu durumda (A), (C)'den alamadığı bu 10.000 TL'lik tutarın yarısını ${ }^{168}$ (B)'den talebe yetkilidir.

3. (B)'nin bu ikinci derece sorumluluğu acaba hangi zamanaşımı süresine bağlıdır?

Kanunda bu konuda bir hüküm yoktur. Kanaatimce bu durumda TBK 73 hükmünde belirtilen 2 ve 10 yıllık zamanaşımı sürelerinin uygulanması gerekir. Şöyle ki,

(A)'nın genel olarak rücu hakk1, tazminatın tamamının ödendiği tarihten itibaren 10 yıllık uzun zamanaşımı süresine bağlı olduğundan, (B)'nin, (C)'den tahsilat yapılamaması nedeniyle ikinci derecede sorumlu olmasinda da bu üst süre uygulama alanı bulur. $\mathrm{Bu}$ süre, yine tazminatın tamamının ödendiği tarihten başlar.

Fakat kanaatimce müteselsil borçluların ikinci derecedeki sorumluluğunda, ikinci derecedeki sorumluluk koşulları gerçekleştiği anda 2 yıllık kısa sürenin de işlemeye başlaması gerektiği kabul edilmelidir. Buna göre, somut

${ }^{168}$ Kanunda (TBK 167 / III) bu tali sorumluluğun eşit paylarla olacağı belirtilmiştir. Fakat bu ifadenin iç ilişkideki pay oranını $\mathrm{m}$ ifade ettiği, yoksa kişi sayısına göre bir eşitliği mi ifade ettiği doktrinde tartışmalıdır. Bkz. TEKINAY / AKMAN / BURCUOĞLU / ALTOP, s. 320; OĞUZMAN / ÖZ, (2017), no.1429; KAPANCI, (2014), s. 534; KILIÇOĞLU, (2014,) s. 756; KILIÇOĞLU, (1979), s. 77; DALCI ÖZDOĞAN, s. 101; ŞAHİN CANER, s. 276; AYAR / ENGIN, s. 1303, dn. 39 ve dn. 40'da belirtilen yazarlar. 
olay bakımından, (B)'nin, (C)'den hiçbir tahsilat yapılamaması ve alacağın aciz belgesine bağlanması nedeniyle (A)'ya karşı olan 5.000 TL'den sorumluluğu, aciz belgesi tarihinden itibaren 2 yıllık zamanaşımı süresine bağlıdır. Fakat bu süre hiçbir biçimde TBK 73 hükmündeki (tazminatın tamamının ödendiği tarihten itibaren işlemeye başlayan) 10 yıllık mutlak süreyi aşmamalıdır.

Rücu talebinde teselsül söz konusu olmadığından, (A)'nın (C) aleyhine dava veya takibe girişmesi, (B) yönünden zamanaşımını kesen sebeplerden olmadığı gözden kaçırılmamalıdır.

\section{SONUC}

Müteselsil borçlulukta iç ilişkideki payından fazla bir tutar için alacaklıyı tatmin eden müteselsil borçlu, payını aşan kısmı diğer müteselsil borçlulardan talep edebilir. $\mathrm{Bu}$ rücu hakkı, çalışmamızda savunulduğu üzere kanundan değil, daima müteselsil borçlular arasındaki özel bir hukuki ilişkiden doğar.

Bu hukuk ilişki bazen bir sözleşme olur. Haksız fiilde bile, müteselsil borçlular arasında bir sözleşme ilişkisinin bulunması mümkündür. Bu durumda rücu hakkının bulunup bulunmadığ 1 ve bu talebin bağlı olduğu zamanaşımı süresi, taraflar arasındaki sözleşme hükümlerine göre belirlenir.

Müteselsil borçlular arasında bir sözleşme ilişkisi yoksa, rücu hakkının bağlı olduğu zamanaşımı süresinin tespitinde, TBK 73 kapsamına giren bir rücu talebinin bulunup bulunmadığ 1 incelenir. TBK 73 kapsamına giren bir rücu talebi söz konusuysa, rücu talebi bu hükümde belirtilen 2 ve 10 yıllık zamanaşımı süresine tabi olur.

Fakat dış ilişkideki borcun doğum sebebi haksız fiil değilse ve müteselsil borçlular arasında bir sözleşme de bulunmuyorsa, rücu talebi bu kez taraflar arasındaki hukuki ilişkinin vekâletsiz iş görme veya sebepsiz zenginleşme olarak nitelenmesine bağlı olarak bu hükümler için geçerli olan zamanaşımı süresine tabi olacaktır.

Bu biçimde belirlenen rücu hakk1, halefiyetle güçlendirilmiştir. Halefiyet, rücu hakkına bağlı bir hukuki imkân niteliği taşır. Fakat müteselsil borçlu dilerse rücu talebini doğrudan halefiyete de dayandırabilir. Bu durumda, ispat yükü kendisinde olan davalı, aralarındaki özel hukuki ilişkiyi iddia ve ispat ettiği ölçüde, bu ilişkiden doğan sınırlamaları ileri sürebilecektir. Halefiyete bağlı olan talep, dış ilişkideki borca bağlı bulunduğundan, bunun zamanaşımı süresi dış ilişkideki zamanaşımı süresiyle aynıdır. 


\section{KAYNAKLAR}

ACAR, Faruk: "Borçlar Kanun Ve Borçlar Kanunu Tasarısı Çerçevesinde Müteselsil Borçluluğa Toplu Bakış (BK.m.141-147)" e-akademi, Hukuk Ekonomi ve Siyasi Bilimler Aylık İnternet Dergisi, Şubat 2010, s.1-20 (http://www.e-akademi.org/incele.asp?konu=BOR\%C7LAR $\% 20$ KANUN\%20VE\% $20 \% 20$ B OR\%C 7 LAR\%20KANUNU\%20 T A S A R I S I \% $20 \%$ C 7 E R \% C 7 E V E S \% D D N D E \% 20 M\%DCTESELS\%DDL\%20BOR\%C7LULU\%D0A\%20TOPLU\%20 BAKI\%DE\%20(BK.m.141-147)\&kimlik=1170695856\&url=makaleler/ facar-1.htm, erişim:01.07.2020).

ACAR, Faruk: "Tam Teselsül - Eksik Teselsül Ayırımı" Prof. Dr. Cevdet Yavuz'a Armağan, İstanbul 2011, s.339-346.

ACAR, Faruk: "Borç İlişkilerinin Üçüncü Kişilere Etkisi, A. Alacaklıya Halef Olma, TBK m. 127" İstanbul Şerhi, Türk Borçlar Kanunu, Yürürlük Kanunu, C. II-III, Madde 83-206, B. 3, Vedat Kitapç1lık, İstanbul 2019, s. $1489-1514$.

AKDAĞ GÜNEY, Necla: "Bankalar Kanunu'na Göre Yönetim Kurulu Üyelerinin Verdikleri Zararla Sınırlı Şahsi Sorumluluklarının İsviçre Borçlar Kanunu Art. 759'da Yer Alan Farklılaştırılmış Teselsül (Differenzierte Solidaritaet) Düzenlemesi İle Karşılaştırılması" Prof.Dr. Hüseyin Ülgen'e Armağan C. II, İstanbul 2007, s. 1207-1240.

AKINTÜRK, Turgut: Müteselsil Borçluluk, Sevinç Matbaası, Ankara 1971.

ALTAY, Sabah: "Müteselsil Borçlulukta Rücu Hakkının Doğumundan Evvel Borçtan Kurtarılma Talebi” MÜHFHAD, C. 17, S. 1-2, s. 394-411.

ANTALYA, Gökhan: Borçlar Hukuku Genel Hükümler, C. V/1, 2, B. 2, Seçkin yayıncılık, Ankara 2019.

ARAT, Ayşe: "Müteselsil Borçlarda Alacaklı ile Borçlular Arasındaki İlişkinin Hüküm ve Sonuçları" SÜHFD, 2018 / II, s. 325-366.

ARĞILLI, İslim: "Sigorta Hukukunda Halefiyet” İBD, 2013 / IV, s. 80-92.

AŞIK, Sebanur: Müteselsil Sorumlulukta Zarar Verenlerin Birbirine Karşı Rücu İlişkisi, Yayınlanmamış Yüksek Lisans Tezi, Ankara 2019.

AYAR, Ahmet / ENGINN, Hande: “Teselsülde Rücu” Prof. Dr. Ali Güzel'e Armağan, C.II, İstanbul 2010, s. 1293-1308. 
BAĞRIAÇIK, Safiye Nur: “Karayolları Zorunlu Mali Sorumluluk Sigortasında Sigortacinın Sorumluluğu” Prof. Dr. M. İlhan Ulusan’a Armağan, C. I, İKÜHFD, 2006 / II, Özel Sayı, Seçkin Yayıncılık, İstanbul 2016, s. 255-275.

BAYSAL, Başak: Haksız Fiil Hukuku, BK m. 49-76, Oniki Levha Yayıncılık, İstanbul 2019.

BERGAMIN, Christof: "Die laengere strafrechtliche Verjaehrungsfrist nach Art. 60 Abs.2 OR" Das neue Verjaehrungsrecht Tagun vom 29. Oktober 2019 in Luzern, Staempfli Verlag, Zürich 2019, s. 35-58.

BOZER, Ali: “Sigortacının Rücu Hakkı” BATIDDER 1964 / III, C. II, s. 477480, (Rücu).

BOZER, Ali: “Sigortacının Rücu'unda Zamanaşımı” BATİDER 1964/III, C. II, s. 473-476, (Zamanaşımı).

BUCHER, Eugen: Schweizerisches Obligationenrecht, 2.Aufl. Schulthess Verlag, Zürich 1988.

CANPOLAT, Ferhat: "Müteselsil Borcun Sona Erme Sebepleri, Borçlar Kanunu Tasarısındaki İlgili Hükümlerin Değerlendirilmesiyle Birlikte" ABD, 2008/III, s. 68-81.

ÇANDARLI, Zahit: "Müteselsil Borçlu ve Alacaklıların Zamanaşımı Kesimi” AD, 1945/12, s. 1288-1295.

ÇAVUŞOĞLU IŞINTAN, Pelin: "Türk Borçlar Kanunu Tasarısında Yer Alan Haksız Fiillerde Teselsül Düzenlemesi Üzerine Düşünceler” Prof. Dr. Erden Kuntalp’e Armağan, GSÜHFD, 2004/1, s. 499-512.

ÇELIK, Nazlı Hilal: “Zamanaşımı, TBK m. 72-75” İstanbul Şerhi, Türk Borçlar Kanunu, Yürürlük Kanunu, C. I, Madde 1-82, B. 3, Vedat Kitapç111k, İstanbul 2019, s. 1098-1108.

ÇİLENTİ KONURALP, Ayşen: "Türk Hukukunda Üçüncü Kişi Yararına Sözleşme Ve Hukukî Niteliği Konusunda Bir Değerlendirme” TBB Dergisi 2020 / 146, s. 153-185.

DALCI ÖZDOĞAN, Nurcihan: Müteselsil Sorumluluk, Seçkin Yayıncılık, Ankara 2015.

ERDEM, Mehmet: Özel Hukukta Zamanaşımı, Oniki Levha Yayıncılık, İstanbul 2010. 
ERDEM, Mehmet: "Zamanaşımı, TBK m.146-161" İstanbul Şerhi, Türk Borçlar Kanunu, Yürürlük Kanunu, C. II-III, Madde 83-206, B. 3, Vedat Kitapç11ı, İstanbul 2019, s. 1761-2002.

EREN, Fikret: Borçlar Hukuku Genel Hükümler, B. 24, Yetkin Yayıncılık, Ankara 2019.

FELLMANN, Walter: "Das neue Verjaehrungsrecht" ZBJV 2020/156, s. 210226.

FRANKO, Nisim: "Borçlar Kanununun 109. Maddesine Göre Halefiyet Halleri” ABD, 1981 / II, s. 202-220 (Halefiyet I).

FRANKO, Nisim: "Borçlar Kanununun 109. Maddesine Göre Halefiyet Halleri II” ABD, 1981 / III, s. 384-391 (Halefiyet II).

GAUCH, Peter / SCHLUEP, Walter R. / EMMENEGGER, Susan: Schweizerisches Obligationenrecht Allgemeiner Teil, B. II, 9. Aufl. Schulthess Verlag, Zurich 2008.

GAUTSCHI, Alain: Solidarschuld und Ausgleich, Dike Verlag, Zürich 2009. GÖKCAN, Hasan Tahsin: Kara Yolları Trafik Kanununa Göre Hukuki Sorumluluk, Tazminat, Sigorta ve Rücu Davaları, Seçkin Yayıncılık, B. 8, Ankara 2014.

GÖKTÜRK, Kürşat / CAN, Mehmet Çelebi: "Farklılaştırılmış Teselsülün Özellikle - Dış İlişki Bakımından Anlamı Ve Bankacılık Kanununun Şahsi İflas Sorumluluğu İle Karşılaştırılması" İnönüÜHFD, 2011 / II, s. 247-282.

GÜRPINAR, Damla: "Haksız Fiil Kaynaklı Zararların Tazmini Bakımından 6098 sayılı Türk Borçlar Kanununun Getirdikleri” İzmir Barosu Dergisi, Mayıs 2012, s. 253-299.

KAPANCI, Berk Kadir: "Müteselsil Sorumluluk, TBK m.61-62" İstanbul Şerhi, Türk Borçlar Kanunu, Yürürlük Kanunu, C. I, Madde 1-82, B. 3, Vedat Kitapç11ı, İstanbul 2019, s. 969-1039.

KAPANCI, Berk Kadir: "Müteselsil Borçluluk, TBK m.162-168” İstanbul Şerhi, Türk Borçlar Kanunu, Yürürlük Kanunu, C. II-III, Madde 83-206, B. 3, Vedat Kitapç11ı, İstanbul 2019, s. 2003-2212.

KAPANCI, Kadir Berk: Birlikte Borçlulukta Borçlular Arası İlişkiler, Vedat Kitapç1lık, İstanbul 2014. 
KARAŞAHIN, Yasin Alperen: "Verjaehrungsverzicht und Vereinbarungen über die Dauer von Verjaehrungsfristen nach Revision des Verjaehrungsrechts" ZBJV 2019/155, s. 731-756.

KARAYALÇIN, Yaşar: "İsviçre Hukukunda Müteselsil Sorumluluk Konusunda Tartışmalar ve Yasal Gelişmeler” ABD, 2007 / IV, s. 107119.

KAYIHAN, Şaban: "Zarar Sigortalarında Sigortacının Halefiyeti” Prof. Dr. Cevdet Yavuz'a Armağan, C. II, MÜHFHAD, 2016 / III, Özel Say1, Beta Yayınc1lık, İstanbul 2016, s. 1595-1624.

KILIÇOĞLU YILMAZ, Kumru: “Tam Üçüncü Kişi Yararına Sözleşme” Prof. Dr. Cevdet Yavuz’a Armağan, C. II, MÜHFHAD, 2016 / III, Özel Say1, Beta Yayınc1lik, İstanbul 2016, s. 1759-1771.

KILIÇOĞLU, Ahmet: "Haksız Fiillerde Müteselsil Sorumluluk ve Geçici Ödemeler" Türk Medeni Kanununun Yürürlüğe Girişinin 80. Yılı Münasebetiyle Düzenlenen Sempozyum, Ankara 2007, s. 163-183.

KILIÇOĞLU, Ahmet: Borçlar Hukuku Genel Hükümler, B. 18, Turhan Yayıncilık, Ankara 2014.

KILIÇOĞLU, Ahmet: Türk Borçlar Hukukunda Kanuni Halefiyet, AÜHF Yayınları, Ankara 1979.

KIRCA, Çiğgdem: “6098 Sayılı Türk Borçlar Kanunu İle Müteselsil Sorumluluk Konusunda Getirilen Yenilikler" Yeni Türk Borçlar Kanunu ve Yeni Türk Ticaret Kanunu Sempozyumu, Vedat Kitapçılık, İstanbul 2013, s. 23-51.

KOLLER, Alfred: Schweizerisches Obligationenrecht Allgemeiner Teil, 3.Aufl. Staempfli Verlag, Bern 2009.

KURT, Leyla Müjde: "Haksız Fiil Sonucu Oluşan Zarardan Birden Çok Kişinin Sorumlu Olduğu Hallerde Rücu Talebinin Tabi Olduğu Zamanaşımı" TBBD, 2011/95, s. 135-162.

MAERKI, Raphael: "Das neue Verjaehrungsrecht - Übergansrechtliche Regeln" Das neue Verjaehrungsrecht Tagung vom 29. Oktober 2019 in Luzern, Hrsg. Fellmann, Walter, Staempfli Verlag AG, Bern 2019, s. 157-201.

MEMIŞ, Tekin: "Sigorta Sözleşmesinden Kaynaklanan Taleplerde Zamanaşımına İliş̧kin Eleştiriler ve Değerlendirmeler” Prof. Dr. Cevdet 
Yavuz'a Armağan, C. II, MÜHFHAD, 2016 / III, Özel Sayı, Beta Yayınc1lık, İstanbul 2016, s. 1931-1943.

NOMER, Haluk N.: Borçlar Hukuku Genel Hükümler, B. 14, Beta Yayınları, İstanbul 2015.

NOMER, Haluk Nami: "Haksız Fiillerde Müteselsil Sorumluluk" Türk

Borçlar Kanunu Sempozyumu, Makaleler - Tebliğler, Derleyen: Doç.

Dr. M. Murat İnceoğlu, Oniki Levha Yayınc1lık, İstanbul 2012, s. 53-60.

NOMER, Haluk Nami: "Halefiyet ile Rücu Hakkı Arasındaki İlişki, Özellikle Sosyal Sigortalar ile Özel Sigortaların Rücu Hakları Bakımından Halefiyetin Rolü” İ̈̈FHM, 1997 / III, s. 243-260.

NOMER, Haluk Nami: "Rücu İstemine İlişkin Zamanaşımı (TBK m.73)" Prof.

Dr. Cevdet Yavuz'a Armağan, MÜHFHAD, Özel Hukuk Sempozyumu Özel Sayıs1, 6098 Sayılı Türk Borçlar Kanunu Hükümlerinin Değerlendirilmesi Sempozyumu, 3-4 Haziran 2011, İstanbul 2011, s. 249-255.

OĞUZMAN, M. Kemal / ÖZ, M. Turgut: Borçlar Hukuku Genel Hükümler C.I, Vedat Kitapç1lık, İstanbul 2018.

OĞUZMAN, M. Kemal / ÖZ, M. Turgut: Borçlar Hukuku Genel Hükümler C.II, Vedat Kitapçılık, İstanbul 2017.

ÖZ, Turgut: “Üçüncü Kişi Yararına Sözleşme, TBK. m.129”' İstanbul Şerhi, Türk Borçlar Kanunu, Yürürlük Kanunu, C. II-III, Madde 83-206, B. 3, Vedat Kitapç1lık, İstanbul 2019, s. 1557-1582.

ÖZEN, Burak: "Kefilin Özel Rücu Talebi ve Bu Talebin Halefiyete Dayanan (Genel) Rücu Talebiyle İlişkisi” Prof. Dr. Rona Serozan'a Armağan, C. II, Oniki Levha Yayıncılık, İstanbul 2011, s. 1445-1480.

PICHONNAZ, Pascal: "Das revidierte Verjaehrungsrecht: Drei bemerkenswerte Punkte" SJZ 2019/115, s. 739-748.

ROTHENBERGER, Adrian: "Die Verjaehrung des Regressanspruchs" Das neue Verjaehrungsrecht Tagung vom 29. Oktober 2019 in Luzern, Hrsg. Fellmann, Walter, Staempfli Verlag AG, Bern 2019, s. 73-101.

ŞAHIN CANER, Ayşenur: Türk Borçlar Kanununda Müteselsil Borçluluk, Oniki Levha Yayınc1lık, İstanbul 2017.

TEKINAY, Selahattin Sulhi / AKMAN, Sermet / BURCUOĞLU, Haluk 
/ ALTOP, Atilla: Borçlar Hukuk Gene Hükümler, Filiz Kitapevi, İstanbul 1993.

TERCIER, Pierre / PICHONNAZ, Pascal / DEVELIOĞLU, H. Murat: Borçlar Hukuku Genel Hükümler, Oniki Levha Yayıncılık, İstanbul 2016.

TURANBOY, Kürşat Nuri: "Müteselsil Sorumluluk Kavramı ve Müteselsil Sorumlulukta Borçlar Kanunun Tasarısının Hükümleri” e-akademi, Hukuk Ekonomi ve Siyasi Bilimler Aylık Internet Dergisi, Aralık 2009, s.1-9 (http://www.e-akademi.org/incele. asp?konu=M\%DCTESELS\%DDL\%20SORUMLULUK\%20 K A V R A M I 20 V E \% 20 M \% C T E S E L S \% D L \% 20 SORUMLULUKTA \% 20BOR\%C 7 LAR\%20KANUNU\%20 TAS ARIS IN IN \% 20 H\% DCK \% D CM LER \% D D \& kimlik=1 261416813\&url=makaleler/kturanboy-1.htm, erişim: 10.07.2020).

TUTUMLU, Mehmet Akif: Zamanaşımı Def’i, Seçkin Yayıncılık, Ankara 2019.

VERDE, Michel: "Die Unterbrechung der Verjaehrung" (Das neue Verjaehrungsrecht Tagung vom 29. Oktober 2019 in Luzern, Hrsg. Fellmann, Walter, Staempfli Verlag AG, Bern 2019, s. 103-134.

VERDE, Michel: "Neues Jahrzehnt - neues Verjaehrungsrecht” AJP 2020, s. 171-186.

VON TUHR, Andreas: Borçlar Hukukunun Umumi Kısmı, C.I-II, B.II, Çev. Edege, Cevat, Yargıtay Yayınları, Ankara 1983.

YAĞCIOĞLU, Ali Haydar: Haksız Fiil Sebebiyle Aynı Zarardan Birden Fazla Kimsenin Müteselsil Sorumluluğu, Adalet Yayıncılık, Ankara 2014.

YEŞİLOVA Aras, Ecehan: Sorumluluk Sigortalarında Zarar Görenin Doğrudan Dava Hakkı (TTK m. 1478) Yetkin Yayıncılık, Ankara 2013. 
